\section{Phase evolution of slag-rich cementitious grouts for immobilisation of nuclear wastes}

\section{Dale P. Prentice}

Department of Materials Science and Engineering, The University of Sheffield, Sheffield, UK (Orcid:0000-0002-4980-8751)

\section{Susan A. Bernal}

Department of Materials Science and Engineering, The University of Sheffield, Sheffield, UK (Orcid:0000-0002-9647-3106)

\section{Mark Bankhead}

National Nuclear Laboratory, Warrington, UK

\author{
Martin Hayes \\ National Nuclear Laboratory, Warrington, UK \\ John L. Provis \\ Department of Materials Science and Engineering, The University of \\ Sheffield, Sheffield, UK (corresponding author: j.provis@sheffield.ac.uk) \\ (Orcid:0000-0003-3372-8922)
}

An updated calcium silicate hydrate (C-S-H) model incorporating aluminium-containing end-members was used for thermodynamic modelling of blended cements using blast-furnace slag and Portland cement (BFS:PC) with ratios of 1:1, 3:1 and 9:1, using GEMSelektor. Selective dissolution and magic angle spinning nuclear magnetic resonance (MAS NMR) studies were performed to determine the degree of hydration (DoH) of the anhydrous material as an input parameter for the modelling work. Both techniques showed similar results for determining the DoH of the BFS within each sample. Characterisation of the hardened cement pastes over $\mathbf{3 6 0}$ days, using X-ray diffraction analysis and MAS NMR, demonstrated that the use of the updated C-S-H model can highlight the effect of different blend ratios and curing ages on the phase assemblages in these cements. Validation using this modelling approach was performed on $\mathbf{2 0}$ year old specimens from the literature to highlight its applicability for modelling later-age blended cements.

\section{Notation}

$A_{\gamma} \quad$ temperature-dependent electrostatic parameter in the extended Debye-Hückel equation

$\dot{a} \quad$ ion size parameter in the extended Debye-Hückel equation, $\mathrm{nm}$

$B_{\gamma} \quad$ pressure-dependent electrostatic parameter in the extended Debye-Hückel equation

$b_{\gamma} \quad$ short-range interaction parameter in the extended Debye-Hückel equation, $\mathrm{kg} \mathrm{mol}^{-1}$

D corrected degree of hydration

$\mathrm{HT}_{\mathrm{m}} \quad$ maximum quantity of hydrotalcite-like phase, $\mathrm{g}$

$\mathrm{HT}_{\mathrm{s}} \quad$ mass of hydrotalcite-like phase created based on percentage of slag reacted, $\mathrm{g}$

I ionic strength of the aqueous electrolyte phase in the extended Debye-Hückel equation, mol kg-1

$m_{\mathrm{MgO}} \quad$ mass of magnesium oxide within the BFS, $\mathrm{g}$

$m_{\mathrm{MgO} / \mathrm{HT}}$ mass percentage of magnesium oxide within hydrotalcite-like phase, wt. \%

$R \quad$ mass of residue after selective dissolution including PC and BFS corrections, $g$

$R_{\mathrm{c}} \quad$ calculated initial residue without any formation of hydrotalcite, $\mathrm{g}$

$X_{j \mathrm{w}} \quad$ molar quantity of water in the extended Debye-Hückel equation, mol

$X_{\mathrm{w}} \quad$ total molar amount of the aqueous phase in the extended Debye-Hückel equation, mol

$z_{i} \quad$ charge of aqueous species $i$

$\gamma_{i} \quad$ activity coefficient of aqueous species $i$

\section{Introduction}

Encapsulation of intermediate level radioactive waste (ILW) in cementitious matrices is the preferred method for its disposal in the UK. Combinations of supplementary cementitious materials (SCMs) and Portland cement (PC) contribute to the grouts used in this process (Atkins and Glasser, 1992). The high $\mathrm{pH}$ of the blended cements, normally 12 or higher (Moranville-Regourd, 2003), is intended to cause the radionuclides to be insoluble, and the cementitious environment creates hydration products that promote the sorption and ionic substitution of key radionuclides (Glasser, 1992; Sharp et al., 2003). Restricting the movement of the radioactive material is the main objective of encapsulation (Collier and Milestone, 2010).

A highly durable cement waste form provides a safer method to store and transport potentially hazardous material (Ojovan and Lee, 2006). Blast-furnace slag (BFS) blended with PC is used extensively for this purpose, at varying degrees of replacement (from 75 to $90 \%$ replacement). High replacement levels are used because of the slower reactivity of BFS with water, which decreases the heat released by hydration of grout constituents during the early stages of curing (Bland and Sharp, 1991; Hill and Sharp, 2002; Utton et al., 2008). Blended cements are also widely available and relatively inexpensive for the purpose of encapsulating a wide range of wastes.

In the UK, $108000 \mathrm{~m}^{3}$ of ILW had already been generated by April 2016, of which $41400 \mathrm{~m}^{3}$ had been converted into 
cemented waste forms awaiting long-term storage, leaving large quantities still awaiting treatment (NDA, 2017). Therefore, owing to the large volumes of waste still awaiting treatment, as well as the need to monitor and maintain the cemented products now in interim storage awaiting final disposal, further understanding of the potential interactions between the cementitious grouts and the encapsulated wastes is necessary. Despite the large volumes of waste being produced, the supply of the precursor materials has been a constant issue over the years (Angus et al., 2010); therefore, a method to be able to predict how the old and new cementitious constituents react to form different phase assemblages is required.

Investigations of cement for immobilisation of radioisotopes have primarily focused on the incorporation of ions within the cement hydrate phases, such as calcium silicate hydrates $(\mathrm{C}-\mathrm{S}-\mathrm{H})$, ettringite and calcium monosulfoaluminate hydrate ('monosulfate'), owing to the variety of cationic and anionic substitutions that may take place within these stable phases. The silicate-chain-based, layered structure of $\mathrm{C}-\mathrm{S}-\mathrm{H}$ offers a variety of sites to host substituents, whether within the silicate chain, such as the replacement of silicon by aluminium to form calcium aluminosilicate hydrate $(\mathrm{C}-\mathrm{A}-\mathrm{S}-\mathrm{H})$ type products (L’Hôpital et al., 2015; Myers et al., 2015a; Richardson and Groves, 1997; Richardson et al., 1993), or as charge balancing ions within the interlayer region (L'Hôpital et al., 2016b; Myers et al., 2014; Richardson and Groves, 1993). The high surface area of the $\mathrm{C}-\mathrm{A}-\mathrm{S}-\mathrm{H}$ gel provides a surface for ionic sorption or substitution for interlayer sites (Gougar et al., 1996). Ettringite $\left(\mathrm{Ca}_{3} \mathrm{Al}_{2} \mathrm{O}_{6} \cdot 3 \mathrm{CaSO}_{4} \cdot 32 \mathrm{H}_{2} \mathrm{O}\right)$ hosts numerous $\mathrm{SO}_{4}{ }^{2-}$ ions located within the channels of columns of calcium and aluminium polyhedra, which provides the possibility for anionic replacement. At lower sulfate concentrations, monosulfate $\left(\mathrm{Ca}_{3} \mathrm{Al}_{2} \mathrm{O}_{6} \cdot \mathrm{CaSO}_{4} \cdot 12 \mathrm{H}_{2} \mathrm{O}\right)$ is more dominant (Durdziński et al., 2017b; Kocaba, 2009; Taylor et al., 2010) and forms a lamellar hexagonal structure. Both ettringite and monosulfate require charge balancing of a cationic structure by exchangeable anions, which can be replaced by anionic radionuclides (Cau Dit Coumes et al., 2009; Gougar et al., 1996; Mobasher et al., 2014). Another main phase associated with BFS-rich cements is a $\mathrm{Mg}$-Al-hydrotalcite-like phase, and although this is well known to act as a good receptor for $\mathrm{Cl}^{-}$and $\mathrm{CO}_{3}{ }^{2-}$ binding (Ke et al., 2016, 2017), its role in the uptake of other important radionuclides still requires further investigation.

The nature and amount of hydration products forming in BFS-PC blended cements are highly dependent on temperature, curing time, $\mathrm{PC}$ and slag content, as well as slag composition (Deschner et al., 2013; Durdziński et al., 2017b; Escalante-García and Sharp, 1998, 2004; Kocaba, 2009; Lothenbach et al., 2008; Myers et al., 2015b; Taylor et al., 2010). Although BFS-PC grouts have been extensively studied over recent decades, evaluation has mostly focused on assessment of young specimens and a small portfolio of samples which have been analysed at regular intervals since the 1990s
(Luke and Lachowski, 2008; Richardson and Groves, 1992; Richardson et al., 1993; Taylor et al., 2010), and therefore there remain open questions around the chemical, mineralogical and microstructural changes these materials will undergo over the timescale relevant for nuclear waste cementation.

Thermodynamic modelling is a very useful tool that can be used to predict how the changes in blend ratios of a cement system will affect the aqueous and solid hydration products in the longer term (Damidot et al., 2011; Lothenbach, 2010; Lothenbach and Winnefeld, 2006). This can be performed using geochemical modelling software packages such as GEMSelektor (GEMS) (Kulik et al., 2013; Wagner et al., 2012), and utilises solid-solution models in conjunction with thermodynamic databases for defined phases to predict the formation of cement hydrates. The key limitation of this method at present is the difficulty in accurately parameterising an endmember model for the complex multi-component hydrates present in cements, based on limited and often conflicting experimental results (Kulik, 2011; Myers et al., 2014; Walker et al., 2016). Therefore, the purpose of this study is to assess the effectiveness of a geochemical model for $\mathrm{C}(-\mathrm{A})-\mathrm{S}-\mathrm{H}$ in predicting phase assemblages of the slag cement systems used in the nuclear industry in the UK. Using this technique, predictions based on the precursor materials used for nuclear waste encapsulation may be performed to quickly and accurately assess whether new supplies of BFS and PC are capable of providing the necessary performance characteristics in the long term.

\section{Experimental methodology}

Mix design

Cementitious grouts composed of 1:1, 3:1 and 9:1 BFS:PC (compositions in Table 1) were produced with a water/solids $(w / s)$ mass ratio of $0 \cdot 35$, cured at $35^{\circ} \mathrm{C}$. These mix ratios and curing temperature conditions were chosen to resemble the current interim storage conditions of ILW waste packages. The powders used were Ribblesdale CEM I 52.5N PC and Port Talbot ground granulated BFS supplied by way of the National Nuclear Laboratory. The mineralogy of the

Table 1. Major constituents of raw materials, as determined by $X$-ray fluorescence (XRF) and represented as oxides

$\begin{array}{lrr}\text { Oxide: wt\% } & \text { PC } & \text { BFS } \\ \text { Calcium oxide }(\mathrm{CaO}) & 63 \cdot 7 & 39 \cdot 2 \\ \text { Silicon dioxide }\left(\mathrm{SiO}_{2}\right) & 20 \cdot 8 & 35 \cdot 1 \\ \text { Aluminium oxide }\left(\mathrm{Al}_{2} \mathrm{O}_{3}\right) & 5 \cdot 1 & 13 \cdot 4 \\ \text { Iron (III) oxide }\left(\mathrm{Fe}_{2} \mathrm{O}_{3}\right) & 2 \cdot 6 & 0 \cdot 2 \\ \text { Magnesium oxide }(\mathrm{MgO}) & 2 \cdot 3 & 9 \cdot 9 \\ \text { Sulfur trioxide }\left(\mathrm{SO}_{3}\right) & 3 \cdot 7 & 0 \cdot 4 \\ \text { Sodium oxide }\left(\mathrm{Na}_{2} \mathrm{O}\right) & 0 \cdot 6 & 0 \cdot 2 \\ \text { Potassium oxide }\left(\mathrm{K}_{2} \mathrm{O}\right) & 0 \cdot 8 & 0.6 \\ \text { Titanium dioxide }\left(\mathrm{TiO}_{2}\right) & 0 \cdot 2 & 0.8 \\ \text { Manganese dioxide }\left(\mathrm{MnO}_{2}\right) & 0 \cdot 1 & 0.2 \\ \text { Phosphorus pentoxide }\left(\mathrm{P}_{2} \mathrm{O}_{5}\right) & 0.2 & -\end{array}$




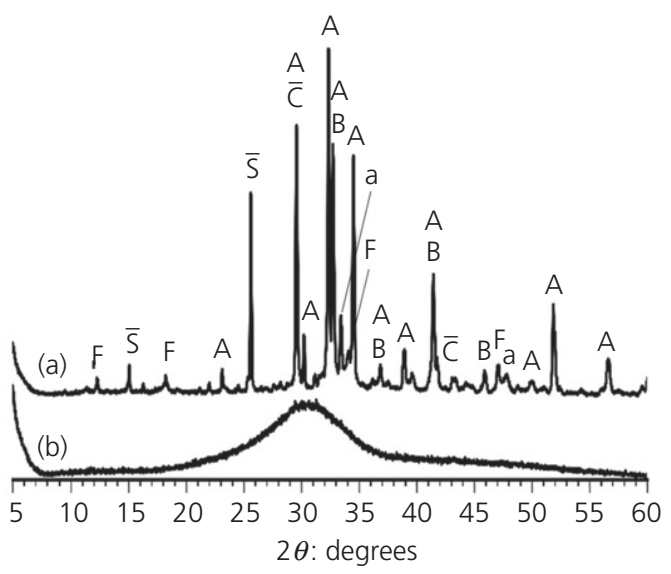

Figure 1. X-ray diffractograms of anhydrous: (a) PC; (b) BFS (A, alite; $B$, belite; $F$, ferrite; a, aluminate; $\bar{C}$, calcite; $\bar{S}$, gypsum)

anhydrous powders can be observed in Figure 1, obtained through X-ray diffraction (XRD) (details in the next section entitled 'Analytical techniques'). Samples were mixed in batches then poured into $50 \mathrm{ml}$ tubes, sealed and stored in an oven at the specified curing temperature until testing.

\section{Analytical techniques}

Upon reaching the specified curing age, hardened specimens were crushed and ground using acetone as a lubricant, to a particle size below $63 \mu \mathrm{m}$. They were then vacuum washed with acetone to ensure hydration had ceased (Ismail et al., 2013).

Analysis of the crystalline phases was performed using powder XRD on a Bruker D2 Phaser instrument with $\mathrm{Cu} \mathrm{K} \alpha$ radiation and a nickel filter. Scans were conducted with a step size of $0.020^{\circ}$, for $2 \mathrm{~s}$ per step. Samples were front loaded by pouring the sample into a sample holder, then smoothed over with a glass tile.

Selective dissolution (Luke and Glasser, 1987; Lumley et al., 1996) was performed to provide a quantitative determination of the degree of hydration of the BFS by dissolving PC and hydration products while leaving slag grains intact. Initially, $93.0 \mathrm{~g}$ of disodium ethylenediaminetetraacetic acid (EDTA $2 \mathrm{H}_{2} \mathrm{O}$ ) was dissolved in a mixture of $250 \mathrm{ml}$ of triethanolamine and $500 \mathrm{ml}$ of water. The solution was transferred to a volumetric flask. $173 \mathrm{ml}$ of diethylamine was added into the solution, then the mixture was made up to $1000 \mathrm{ml}$ with water.

For each extraction test, $50 \mathrm{ml}$ of the above solution was pipetted into a beaker and diluted to $800 \mathrm{ml}$ with distilled water. After the diluted solution was brought to a temperature of $20 \cdot 0 \pm 2{ }^{\circ} \mathrm{C}, 0 \cdot 5000 \mathrm{~g}$ of dried and ground sample (particle size smaller than $63 \mu \mathrm{m}$ ), weighed to the nearest $0.0001 \mathrm{~g}$, was sprinkled over the surface of the solution. The solution was stirred using a magnetic mixer for $120 \pm 5$ min maintaining a constant temperature, then filtered under vacuum through a
$90 \mathrm{~mm}$ dia. Whatman $\mathrm{GF} / \mathrm{C}$ filter which had been previously washed with $100 \mathrm{ml}$ of distilled water, dried at $105^{\circ} \mathrm{C}$ and weighed. The residue was washed five times with $10 \mathrm{ml}$ of distilled water per washing, dried at $105^{\circ} \mathrm{C}$ for $1 \mathrm{~h}$ and weighed to the nearest $0.0001 \mathrm{~g}$.

Anhydrous PC and BFS were dissolved by EDTA solution using the same method as used for the hydrated samples, to determine the proportions of these powders that dissolved. Corrections were thus applied to the data for the hydrated samples, to account for the minor amounts of PC remaining after selective dissolution, the few per cent of anhydrous slag that was dissolved, and the hydrotalcite-group minerals that are not dissolved along in the residue (Dyson et al., 2007; Luke and Glasser, 1987). It was assumed that the magnesium oxide $(\mathrm{MgO})$ content of the slag would react to form quintinite $\left(\mathrm{Mg}_{4} \mathrm{Al}_{2}(\mathrm{OH})_{12} \mathrm{CO}_{3} \cdot 4 \mathrm{H}_{2} \mathrm{O}\right)$, which is insoluble in EDTA.

1. $\mathrm{HT}_{\mathrm{m}}=\frac{m_{\mathrm{MgO}}}{m_{\mathrm{MgO} / \mathrm{HT}} / 100}$

2. $\mathrm{HT}_{\mathrm{s}}=R \times \mathrm{HT}_{\mathrm{m}}$

3. $D=\frac{R\left(100+m_{\mathrm{MgO} / \mathrm{HT}}\right)}{100}$

4. $R_{\mathrm{c}}=D-\mathrm{HT}_{\mathrm{s}}$

where $\mathrm{HT}_{\mathrm{m}}$ is the maximum quantity of this hydrotalcitegroup phase (mineralogically resembling quintinite as a phase with a $4: 2 \mathrm{Mg}$ :Al ratio) formed by $100 \%$ hydration of slag $(29.93 \mathrm{~g}) ; m_{\mathrm{MgO}}$ is the mass of magnesium oxide within the BFS; $m_{\mathrm{MgO} / \mathrm{HT}}$ is the mass percentage of magnesium oxide within 'quintinite' $(33.08 \mathrm{wt} \%)$; $\mathrm{HT}_{\mathrm{s}}$ is the mass of 'quintinite' created based on the percentage of slag reacted; $R$ is the residue after dissolution including PC and BFS corrections; $D$ is the corrected degree of hydration; and $R_{\mathrm{c}}$ is the calculated initial residue without any form of hydrotalcite remaining.

These calculations assume that all of the available magnesium oxide is used to form 'quintinite'. Equations 2-4 are solved iteratively, replacing $R$ with $D$ each time. The sum of squared errors (SSE) between the iterated initial residue and the calculated initial residue was minimised to obtain the actual degree of hydration of the slag.

\section{${ }^{27} \mathrm{Al}$ and ${ }^{29} \mathrm{Si}$ MAS NMR}

Solid-state ${ }^{27} \mathrm{Al}$ and ${ }^{29} \mathrm{Si}$ magic angle spinning nuclear magnetic resonance (MAS NMR) spectra were collected on a Varian VNMRS $400(9 \cdot 4 \mathrm{~T})$ spectrometer with either a $4 \mathrm{~mm}$ 
zirconia (for ${ }^{27} \mathrm{Al}$ ) or $6 \mathrm{~mm}$ zirconia (for ${ }^{29} \mathrm{Si}$ ) rotor. The ${ }^{27} \mathrm{Al}$ MAS NMR single-pulse experiments were collected at $104 \cdot 198 \mathrm{MHz}$ using the following parameters: $14 \mathrm{kHz}$ spinning speed, minimum of 5700 scans, pulse width of $1 \mu$ s $\left(25^{\circ}\right)$ and a $0 \cdot 2 \mathrm{~s}$ relaxation delay. The ${ }^{29} \mathrm{Si}$ MAS NMR single-pulse experiments were recorded at $79.435 \mathrm{MHz}$ using the following parameters: $6.8 \mathrm{kHz}$ spinning speed, minimum of 7000 scans, pulse width of $4.7 \mu \mathrm{s}\left(90^{\circ}\right)$ and a relaxation delay of $5 \mathrm{~s}$. Poulsen et al. (2009) showed that a $5 \mathrm{~s}$ relaxation delay may result in an under-quantification of belite as there may not be enough time for the nuclei to fully relax prior to the next pulse, depending on the iron content of the cement tested, and its incorporation into different clinker phases. Edwards et al. (2007) also showed a difference between the intensity ratio of alite to belite as a function of relaxation delay; however, for delays between 3 and $70 \mathrm{~s}$, the difference was minimal. It is also not clear whether differences in relaxation behaviour between different $\mathrm{Si}$ environments in the hydrate products will have a significant influence on quantification under the experimental conditions used here. Therefore, no correction of the silicon intensities for this effect was performed here, and the error in the quantification of resonances due to the differences in relaxation behaviour between different silicon sites is estimated to be $\pm 5 \%$.

${ }^{29} \mathrm{Si}$, and ${ }^{27} \mathrm{Al}$ chemical shifts are referenced to external samples of tetramethylsilane (TMS), and a 1.0 M aqueous solution of aluminium nitrate $\left(\mathrm{Al}\left(\mathrm{NO}_{3}\right)_{3}\right)$, respectively.

Data collected from these scans were used to: $(a)$ determine the degree of hydration for direct comparison with the results obtained through selective dissolution; $(b)$ obtain the degree of hydration of clinker phases; and (c) identify poorly crystalline reaction products which are difficult to observe by XRD.

Deconvolutions were performed, using non-linear minimisation of the sum of squared errors using Gaussian curves, to obtain the best fit for comparing the deconvolution with the experimental data (Bernal et al., 2013, 2014; Myers et al., 2015a, 2015c). Constraints were placed on the line widths and peak positions dependent on the peak being analysed, as detailed below.

Quantification and deconvolution of the anhydrous PC was performed using nine overlapping peaks with varying line widths for alite $(-64.5$ to $-76.5 \mathrm{ppm})$ and a single peak for belite $(-71 \cdot 3 \mathrm{ppm})$ with an observed line width (full width at halfmaximum (FWHM)) of $0.33 \mathrm{ppm}$ (Poulsen et al., 2009) (Figure 2). A relative belite to alite intensity of 0.13 was determined. This relative intensity was used in conjunction with the calcium oxide $(\mathrm{CaO})$ and silicon dioxide $\left(\mathrm{SiO}_{2}\right)$ contents determined by X-ray fluorescence (XRF) (Table 1) to determine the quantity of alite and belite available in the PC (Poulsen et al., 2009). This calculation is in good agreement with the quantity of alite and belite determined using the modified Taylor-Bogue

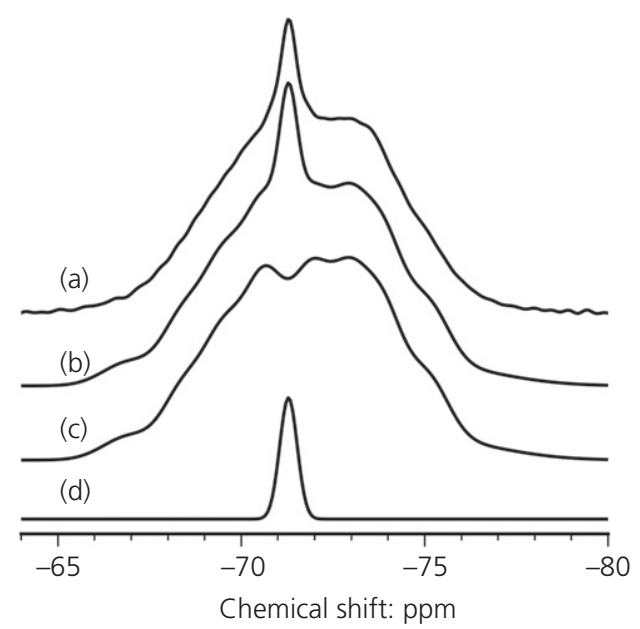

Figure 2. Fitting of the ${ }^{29}$ Si MAS NMR spectrum of anhydrous PC: (a) experimental data; (b) fitted deconvolution; (c) alite spectrum; (d) belite spectrum

Table 2. Clinker phases present in anhydrous PC, as quantified by ${ }^{29} \mathrm{Si}$ MAS NMR and by the Taylor-Bogue method

\begin{tabular}{lcc} 
& ${ }^{29}$ Si MAS NMR & Taylor-Bogue \\
\hline Alite & $72 \cdot 6$ & 71.9 \\
Belite & 7.6 & 6.8 \\
Aluminate & - & 8.0 \\
Ferrite & - & 7.7
\end{tabular}

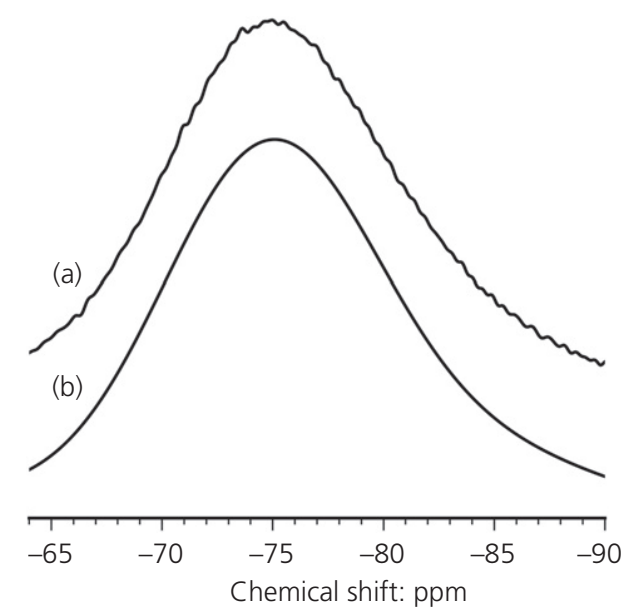

Figure 3. Fitting of the ${ }^{29} \mathrm{Si}$ MAS NMR spectrum of anhydrous slag: (a) experimental data; (b) fitted deconvolution

method (Taylor, 1989) as seen in Table 2. These clinker compositions were used to define the thermodynamic modelling precursor values. Fitting of the anhydrous BFS showed a large, broad resonance from -65 to $-90 \mathrm{ppm}$ (Figure 3). It was assumed that all hydration of the anhydrous material was congruent. 
Table 3. Thermodynamic data for the end-members in the solid-solution model for $\mathrm{C}-\mathrm{A}-\mathrm{S}-\mathrm{H}$

\begin{tabular}{|c|c|c|c|c|}
\hline End-member & Composition & $\Delta_{\mathrm{f}} \mathrm{H}: \mathbf{k J} / \mathrm{mol}$ & $\Delta_{\mathrm{f}} \mathrm{G}: \mathrm{kJ} / \mathrm{mol}$ & Ref. \\
\hline $5 C A$ & $(\mathrm{CaO})_{1 \cdot 25}\left(\mathrm{Al}_{2} \mathrm{O}_{3}\right)_{0.125}\left(\mathrm{SiO}_{2}\right)_{1}\left(\mathrm{H}_{2} \mathrm{O}\right)_{1.625}$ & -2491 & -2293 & Myers et al. (2014) \\
\hline INFCA & $(\mathrm{CaO})_{1}\left(\mathrm{Al}_{2} \mathrm{O}_{3}\right)_{0.15625}\left(\mathrm{SiO}_{2}\right)_{1 \cdot 1875}\left(\mathrm{H}_{2} \mathrm{O}\right)_{1.65625}$ & -2551 & -2343 & Myers et al. (2014) \\
\hline $\mathrm{T} 2 \mathrm{C}$ & $(\mathrm{CaO})_{1.5}\left(\mathrm{SiO}_{2}\right)_{1}\left(\mathrm{H}_{2} \mathrm{O}\right)_{2.5}$ & -2721 & $-2300^{a}$ & Myers et al. (2014) \\
\hline T5C & $(\mathrm{CaO})_{1.25}\left(\mathrm{SiO}_{2}\right)_{1.25}\left(\mathrm{H}_{2} \mathrm{O}\right)_{2.5}$ & -2780 & -2517 & Myers et al. (2014) \\
\hline TobH & $(\mathrm{CaO})_{1.25}\left(\mathrm{SiO}_{2}\right)_{1.5}\left(\mathrm{H}_{2} \mathrm{O}\right)_{2.5}$ & -2831 & -2560 & Myers et al. (2014) \\
\hline JenD & $(\mathrm{CaO})_{1.5}\left(\mathrm{SiO}_{2}\right)_{0.67}\left(\mathrm{H}_{2} \mathrm{O}\right)_{2.5}$ & -2400 & -2170 & Kulik (2011) \\
\hline
\end{tabular}

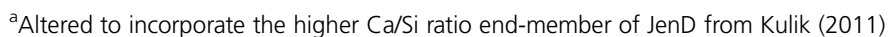

\section{Thermodynamic modelling method}

Thermodynamic modelling was performed using GEMSelektor v3 (Kulik et al., 2013; Wagner et al., 2012) using the CEMData14 database which is an updated version of CEMData07 (Lothenbach et al., 2008). GEMS utilises a Gibbs energy minimisation algorithm which determines the most stable phase assemblage. Included within this study is a solid-solution model for $\mathrm{C}-\mathrm{A}-\mathrm{S}-\mathrm{H}$, adapted from the work of Myers et al. (2014) and Kulik (2011), in Table 3. This adaptation was used to provide a greater calcium/silicon $(\mathrm{Ca} / \mathrm{Si})$ ratio within the modelled $\mathrm{C}-\mathrm{A}-\mathrm{S}-\mathrm{H}$ gel to describe $\mathrm{BFS}: \mathrm{PC}$ cements, as opposed to the alkali-activated slags for which the Myers model was originally developed. A similar approach was also adopted by Elakneswaran et al. (2016) using PHREEQC (Appelo and Postma, 2005; Parkhurst and Appelo, 2013). A solid solution model was used to represent a magnesium aluminum layered double hydroxide (MA-OH-LDH (Myers et al., 2014)), which replaced the $\mathrm{OH}-$ hydrotalcite phase found within CEMData14 to better represent the magnesium aluminate hydrate $(\mathrm{M}-\mathrm{A}-\mathrm{H})$ phase.

The activity coefficients of aqueous species $\left(\gamma_{i}\right)$ were determined using the Truesdell-Jones equation, which is an extension of the Debye-Hückel equation (Equation 5) (Helgeson et al., 1981).

5. $\log _{10} \gamma_{i}=\frac{-A_{\gamma} z_{i}^{2} \sqrt{I}}{1+\dot{a} B_{\gamma} \sqrt{I}}+b_{\gamma} I+\log _{10} \frac{X_{j \mathrm{w}}}{X_{\mathrm{w}}}$

Here $\gamma_{i}$ and $z_{i}$ are the activity coefficient and charge of the $i$ th aqueous species, respectively; $A_{\gamma}$ and $B_{\gamma}$ are temperature- and pressure-dependent coefficients; $I$ is the molal ionic strength; $X_{j \mathrm{w}}$ is the molar quantity of water; and $X_{\mathrm{w}}$ is the total molar amount of the aqueous phase. A common ion size parameter, $\dot{a}(0.367 \mathrm{~nm})$, and short-range interaction parameter, $b_{\gamma}$ $(0 \cdot 123 \mathrm{~kg} / \mathrm{mol})$, were used, treating potassium hydroxide $(\mathrm{KOH})$ as the background electrolyte (Helgeson et al., 1981).

\section{Results}

\section{$\mathrm{X}$-ray diffraction}

X-ray diffractograms highlighting the impact of the varying levels of slag in the hydration products of the blended cements assessed are depicted in Figure 4. Phases present for each curing time and blend ratio are portlandite (ICSD \#15471), calcium hemicarboaluminate-AFm (hemicarbonate, PDF \#00036-0129), calcium monocarboaluminate-AFm (monocarbonate, PDF \#00-036-0377), calcium monosulfoaluminate-AFm (monosulfate, ICSD \#100138), a hydrotalcite-like phase (PDF \#00-014-0525), ettringite (ICSD \#16045) and C-A-S-H (PDF 34-0002).

In the 1:1 BFS:PC grout, evidence of the formation of ettringite (with a distinctive peak at $9 \cdot 08^{\circ} 2 \theta$ ) can be seen at each age tested; however, between $28 \mathrm{~d}$ and $56 \mathrm{~d}$ the intensity of this peak drops just as a slight increase in monosulfate $\left(9 \cdot 93^{\circ} 2 \theta\right)$ emerges. The ettringite transforms into monosulfate when the ratio of $\mathrm{SO}_{4}{ }^{2-}$ to $\mathrm{Al}^{3+}$ decreases (Clark and Brown, 1999), as is the case as more slag reacts. The 3:1 BFS:PC system exhibits a very small ettringite peak intensity after $28 \mathrm{~d}$ and none at later curing ages, while the 9:1 blend exhibits no ettringite and has a much more distinct monosulfate peak.

Other AFm phases, such as hemicarboaluminate and monocarboaluminate, are detected $\left(10.75^{\circ}\right.$ and $\left.11.5^{\circ} 2 \theta\right)$ as a result of reaction of the small amount of calcite in the cement (as identified by XRD, Figure 4) during hydration, and potentially some superficial carbonation contamination of the samples. The availability of calcite restricts the formation of monosulfate (Schöler et al., 2015), leading to a weak reflection assigned to this phase within the 1:1 grout. Within the 3:1 and 9:1 grouts the monosulfate peak is more pronounced compared with grouts with lower BFS content, as the sulfate levels are not high enough to form ettringite at the elevated curing temperature used here $\left(35^{\circ} \mathrm{C}\right)$, except perhaps in the very early stages of hydration, and instead AFm phases were formed.

The hydrotalcite-like phase is formed as a solid solution with a varying $\mathrm{Mg}$ :Al ratio, which impacts its crystal structure (Gastuche et al., 1967; Pausch et al., 1986); therefore, the position of its basal reflection peak may vary between $11 \cdot 2^{\circ}$ and $11 \cdot 6^{\circ} 2 \theta$ (Ke et al., 2016, 2017; Richardson, 2013). All three grouts assessed have distinct peaks at $11 \cdot 6^{\circ} 2 \theta$; within the $1: 1$ grout this can also be attributed to monocarbonate; however, for the 3:1 and 9:1 grouts it is likely that this peak can instead be attributed to a hydrotalcite-like phase. The magnesium oxide content of the slag used in this study is $9.9 \mathrm{wt} \%$ Table 1 , 


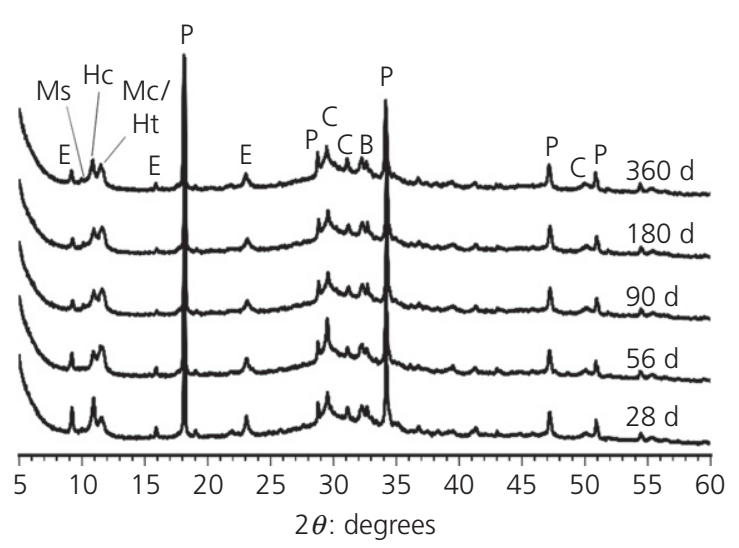

(a)

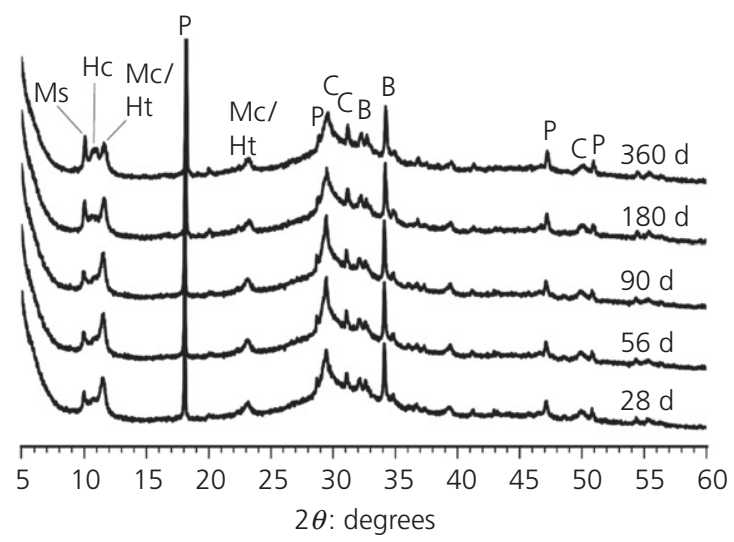

(b)

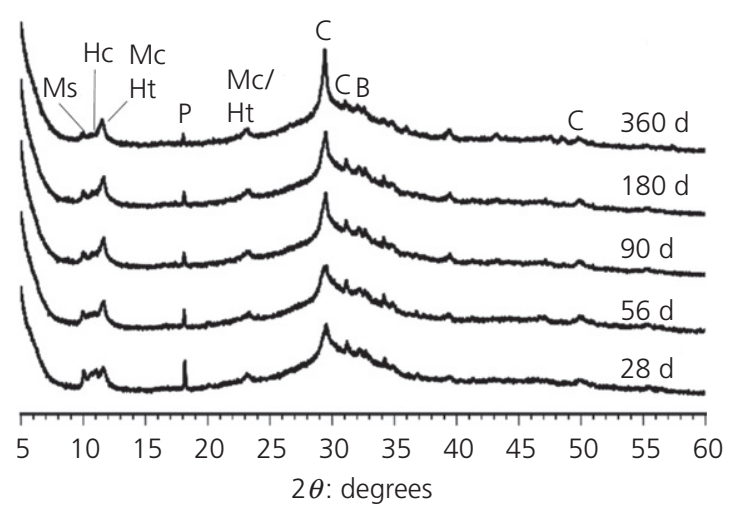

(c)

Figure 4. X-ray diffractograms of hydrated BFS:PC: (a) 1:1; (b) $3: 1$; (c) 9:1 ratios, up to a curing time of $360 \mathrm{~d}$ (P, portlandite; $\mathrm{Mc}$, monocarbonate; $\mathrm{Ht}$, hydrotalcite; Ms, monosulfate; $\mathrm{E}$, ettringite; C, C-A-S-H; B, belite)

which is sufficient for hydrotalcite-group minerals to form in slag-dominated binders (Provis and Bernal, 2014). There is also less calcite available to form carboaluminate phases when the PC content is low, which further supports this line of reasoning. The peaks corresponding to the hydrotalcite-like phase have a much greater intensity in the 3:1 grout than the others, which is attributed to the greater degree of hydration of slag in this cement.
Portlandite and $\mathrm{C}-\mathrm{A}-\mathrm{S}-\mathrm{H}$ gel were the hydration products with the highest peak intensities for the 1:1 and 3:1 grouts. The peak intensity of portlandite decreased with the increasing of BFS content, and in the case of the 9:1 grout, at longer curing times. The consumption of portlandite with time in the 9:1 grout leads to the formation of more $\mathrm{C}-\mathrm{A}-\mathrm{S}-\mathrm{H}$, as more silicon becomes available from the dissolution of slag, as the hydration progresses.

\section{${ }^{27}$ AI MAS NIMR}

Figure 5 includes the ${ }^{27} \mathrm{Al}$ MAS NMR spectra of the anhydrous PC and BFS, along with those of the hydrated samples. The spectrum of the anhydrous BFS displays a very broad resonance between 50 and $80 \mathrm{ppm}$, centred around $67 \mathrm{ppm}$. This is consistent with a tetrahedral aluminium coordination state. Anhydrous cement contains two aluminium-containing phases: tricalcium aluminate (aluminate) and tetracalcium aluminoferrite (ferrite). From the broad peak around $81 \mathrm{ppm}$ (Andersen et al., 2003, 2006) and the sharp peak at $9 \cdot 4 \mathrm{ppm}$ it is assumed that only aluminate can be identified here by NMR, owing to the suppression of the signal from the ferrite phase, which can be attributed to the close proximity of iron to the aluminium nuclei in that phase (Brunet et al., 2010).

Samples cured for $28 \mathrm{~d}$ or more, across all blend ratios, do not display any evidence of the $\mathrm{C}_{3} \mathrm{~A}$ peak at $81 \mathrm{ppm}$, indicating that essentially all of the aluminate in the PC has reacted. Within the Al(IV) region, a shoulder emerges to the left of the slag peak at $71 \mathrm{ppm}$ for all samples. A resonance at this chemical shift is indicative of aluminium substitution within the C-S-H silicate chains (Andersen et al., 2003; Faucon et al., 1999; Pardal et al., 2012; Richardson et al., 1994; Sun et al., 2006). There is clearly a greater influence in the $\mathrm{Al}(\mathrm{IV})$ region with increasing slag content in the grouts. In the 1:1 grouts there is only a slight shoulder on the underlying broad feature; however, in the 3:1 and particularly the 9:1 grout the peak at $71 \mathrm{ppm}$ becomes more defined. The increasing definition of the $71 \mathrm{ppm}$ peak indicates more incorporation of aluminium within the $\mathrm{C}-\mathrm{S}-\mathrm{H}$ gel, which takes place mainly at the $\mathrm{Q}^{2}$ bridging sites within the dreierketten silicate chain structure (L'Hôpital et al., 2016a; Richardson, 2014).

The $\mathrm{Al}(\mathrm{V})$ species exhibited at $36 \mathrm{ppm}$ was identified in all formulations as interlayer charge balancing aluminium (denoted IT) (Sun et al., 2006).

Noticeable changes occur within the $\mathrm{Al}(\mathrm{VI})$ region of the spectra between 0 and $20 \mathrm{ppm}$ as a function of curing time and slag content. Within this region it is evident that ettringite is only observed, at around 13 ppm (Andersen et al., 2003, 2006), in the 1:1 grout from 28 to $360 \mathrm{~d}$. The sharp ettringite peak appears to become less defined at longer curing times. This peak is not evident at all in the 3:1 and 9:1 grouts, consistent with the XRD data (Figures 4(b) and 4(c)). There are clearly not enough sulfate ions within the solution to stabilise the ettringite in the lower PC containing grouts and for later age 1:1 grouts. 


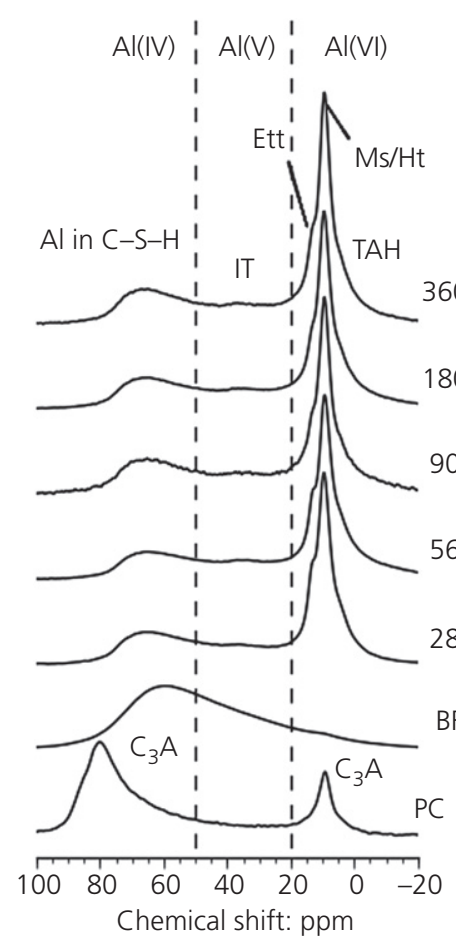

(a)

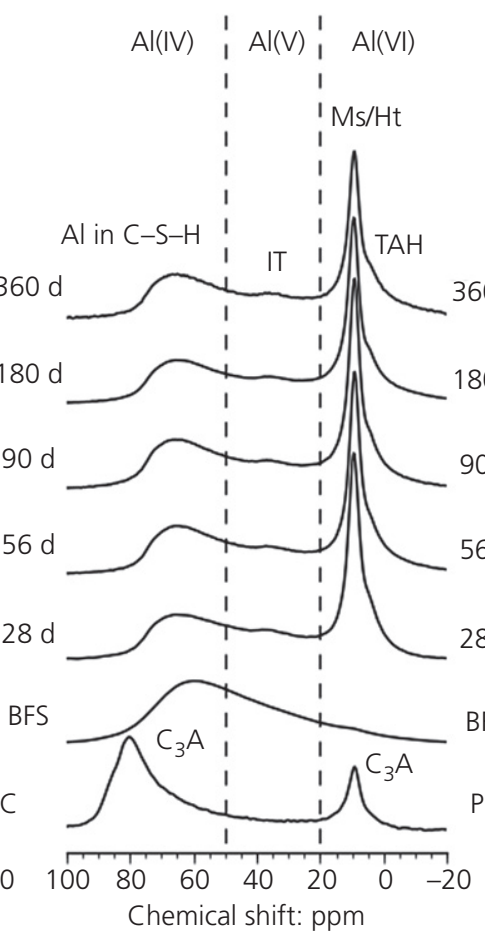

(b)

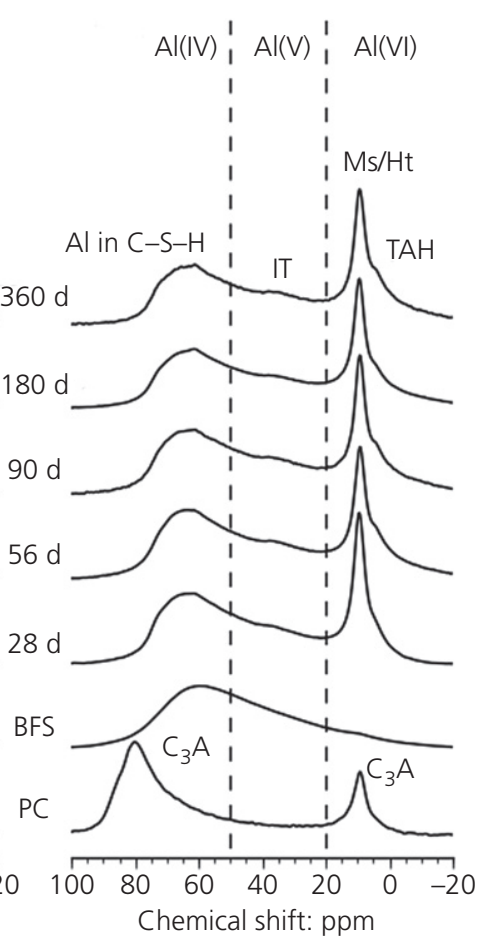

(c)

Figure 5. ${ }^{27}$ Al MAS NMR spectra for: (a) 1:1; (b) 3:1; (c) 9:1 BFS:PC grouts

Clear evidence of AFm phase formation can be seen at $9.8 \mathrm{ppm}$; this can be attributed to monosulfate, hemicarbonate and/or monocarbonate owing to the interchangeability of the charged ion within AFm phases, $\left[\mathrm{Ca}_{2}\left(\mathrm{Al}(\mathrm{OH})_{6}\right) \cdot \mathrm{X} \cdot x \mathrm{H}_{2} \mathrm{O}\right]$ where $\mathrm{X}$ is one unit of a single charged ion or half a unit of a doubly charged ion (Taylor, 1990). This peak may also indicate the presence of octahedral aluminium in hydrotalcite (expected at $9 \cdot 7 \mathrm{ppm}$, so strongly overlapping the AFm resonance). All of these phases were identified in these grouts by XRD (Figure 4) and contribute to the peak intensity in this region. A stronger resonance at this chemical shift was observed in the 1:1 grout as a result of the presence of larger amounts of cement supplying calcite and gypsum. At $3.9 \mathrm{ppm}$, the third aluminate hydrate (TAH) was identified in all grouts and curing times. The lack of sulfate ions and an increase in aluminium present in the cements with the higher BFS contents leads to a more distinct resonance assigned to the TAH phase (Andersen et al., 2006).

\section{${ }^{29}$ Si MAS NMR}

Figure 6 shows the ${ }^{29} \mathrm{Si}$ MAS NMR spectra of each sample analysed; Figures 6(a), 6(c) and 6(e) show examples of the deconvoluted ${ }^{29}$ Si MAS NMR of the 1:1, 3:1 and 9:1 grouts, respectively, after $360 \mathrm{~d}$ of curing, while Figures 6(b), 6(d) and 6(f) show the full sets of spectra as a function of curing time. In conducting the deconvolutions, peaks associated with the $\mathrm{C}-\mathrm{A}-\mathrm{S}-\mathrm{H}$ gel were limited to a line width of $3.5 \mathrm{ppm}$ (FWHM) and the peak positions were allowed to vary within $\pm 0 \cdot 1 \mathrm{ppm}$ of the values provided in Table 4 , to account for the variation of the local environments of silicon within this disordered phase.

The broad glassy slag peaks overlap the signals from unreacted alite and belite, alongside the $\mathrm{Q}^{0}, \mathrm{Q}^{1}(\mathrm{I}), \mathrm{Q}^{1}(\mathrm{II})$ and $\mathrm{Q}^{2}(1 \mathrm{Al})$ sites of $\mathrm{C}-\mathrm{A}-\mathrm{S}-\mathrm{H}$ gel, where the two $\mathrm{Q}^{1}$ environments are distinguished by the nature of the charge-balancing cations (monovalent and divalent), whose differing field strengths lead to the observation of separate resonances (Bernal et al., 2013; Myers et al., 2014). The slag peak overlaps the monomeric and dimeric silicate species $\left(\mathrm{Q}^{0}, \mathrm{Q}^{1}(\mathrm{I})\right.$ and $\left.\mathrm{Q}^{1}(\mathrm{II})\right)$ to a significant extent, which may impact the quantification of the $\mathrm{Ca} / \mathrm{Si}$ ratio within the $\mathrm{C}-\mathrm{A}-\mathrm{S}-\mathrm{H}$ gel. The site located at $-74.0 \mathrm{ppm}$ represents a hydrated silicon monomer, $\mathrm{Q}^{0}$; however, the precise structure in which this site is located is still unknown. Previous studies have highlighted that this silicon environment is linked with greater slag content within the BFS:PC system (Bernal et al., 2013, 2014; Richardson et al., 1993), and this was the case for the 3:1 grout as seen in Table 5, where raising the slag content and increasing the hydration of the slag results in a greater $Q^{0}$ intensity than was observed for the 1:1 grout. This was not the case for the 9:1 ratio; it is possible that the lower degree of slag hydration in the 9:1 system resulted in a lower intensity for this peak.

Increased PC content resulted in the presence of more $\mathrm{Q}^{1}$ sites due to the higher level of calcium supplied by PC. Correspondingly, the $\mathrm{Q}^{1}$ prevalence decreased, and $\mathrm{Q}^{2}(1 \mathrm{Al})$ and 


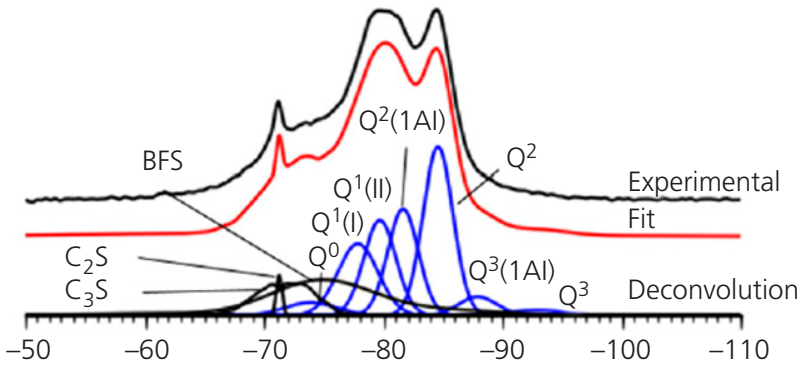

(a)

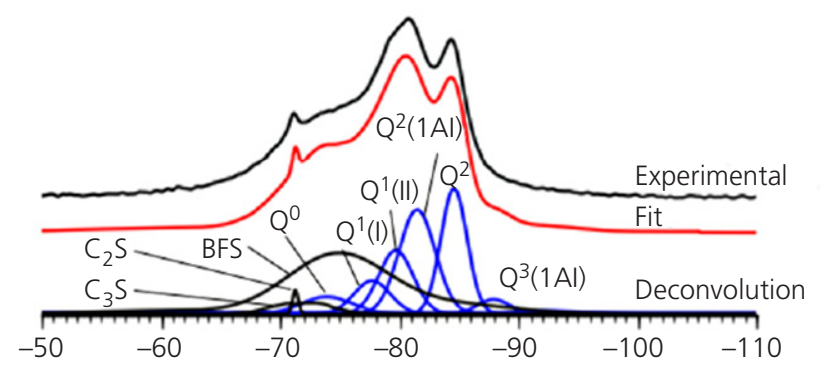

(c)

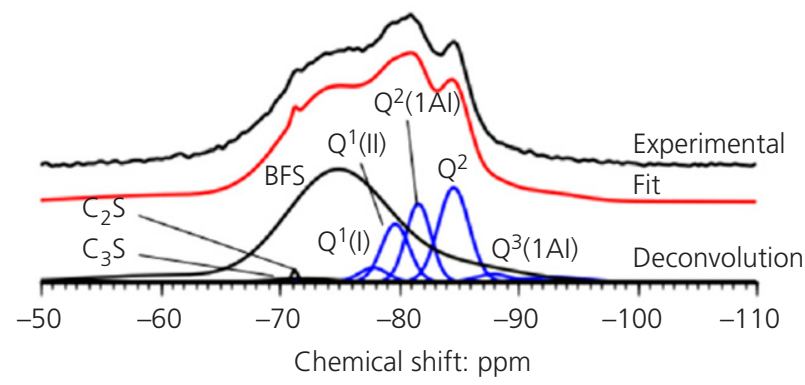

(e)

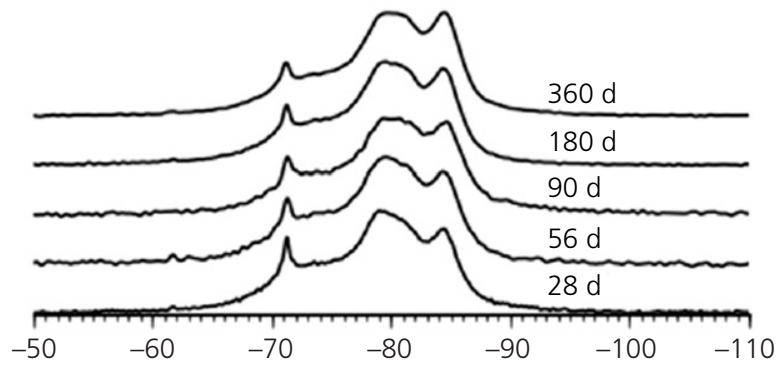

(b)

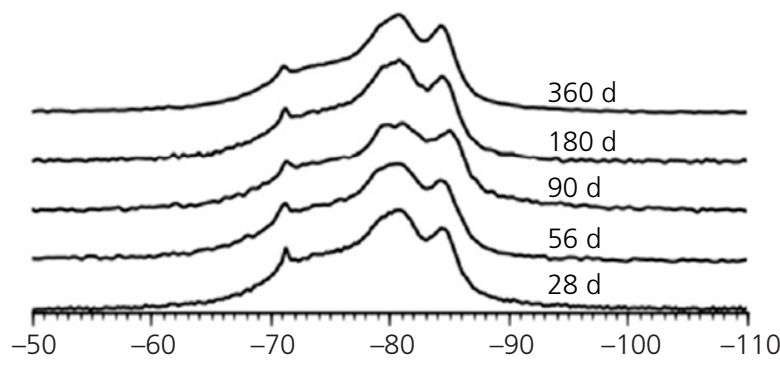

(d)

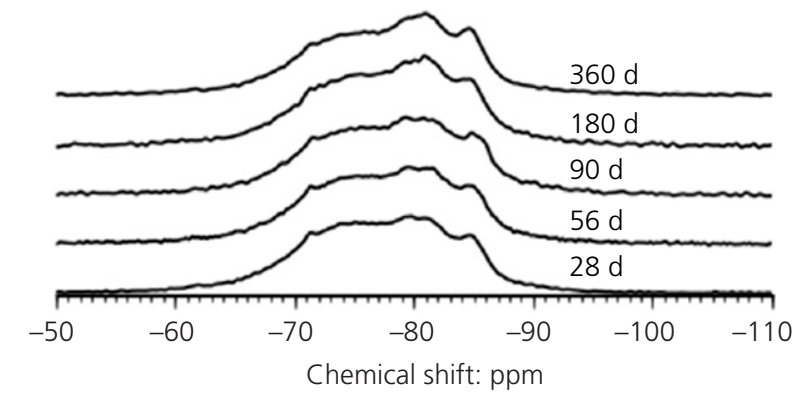

(f)

Figure 6. Example deconvolutions of ${ }^{29} \mathrm{Si}$ MAS NMR spectra for: (a) 1:1; (c) 3:1; (e) 9:1 grouts after $360 \mathrm{~d}$, and ${ }^{29}$ Si MAS NMR spectra for: (b) $1: 1 ;$ (d) $3: 1 ;$ (f) $9: 1$ grouts from $28 d$ to $360 d$ of curing

Table 4. Site allocations for silicon environments in ${ }^{29}$ Si MAS NMR spectra

\begin{tabular}{|lc}
\hline Silicon site & Chemical shift: ppm \\
\hline$Q^{0}$ & $-74 \cdot 0$ \\
$Q^{1}(I)$ & $-77 \cdot 8$ \\
$Q^{1}(I I)$ & $-79 \cdot 8$ \\
$Q^{2}(1 A l)$ & $-81 \cdot 6$ \\
$Q^{2}$ & $-84 \cdot 7$ \\
$Q^{3}(1 A l)$ & $-88 \cdot 0$ \\
$Q^{3}$ & $-93 \cdot 0$
\end{tabular}

$\mathrm{Q}^{2}$ increased, over time as more slag hydrated, thus increasing the amount of silicon available to extend the silicon chains within the $\mathrm{C}-\mathrm{A}-\mathrm{S}-\mathrm{H}$ gel. The chemical shift values used in the deconvolutions for the silicon linked to the aluminium substituted sites $\left(\mathrm{Q}^{2}(1 \mathrm{Al})\right)$ and the paired silicon sites $\left(\mathrm{Q}^{2}\right)$ were more similar to those used in the literature for white PC and BFS:PC (Dai et al., 2014; Dyson et al., 2007; Skibsted and Andersen, 2013;
Sun et al., 2006) than those found in alkali-activated slag (Bernal et al., 2013), as the chemical environments of these peaks are influenced by the alkali concentration. Each specimen exhibited signs of aluminium substitution within a cross-linking site in the $\mathrm{C}-\mathrm{A}-\mathrm{S}-\mathrm{H}$ gel $\left(\mathrm{Q}^{3}(1 \mathrm{Al})\right)$ at $-88 \mathrm{ppm}$, and small signs of crosslinking silicon $\left(\mathrm{Q}^{3}\right)$ at $-93 \mathrm{ppm}$. These peak intensities are much smaller than the other peaks, and are observed at similar levels across each time and blend ratio. Cross-linking is most dominant within the 1:1 and 9:1 systems, where aluminium substitution is most prevalent.

Table 6 summarises the structural characteristics of the C-A-S-H gel in each sample, calculated from the deconvoluted NMR spectra (Richardson, 2014). The mean chain length (MCL) (Equation 6) was seen to increase with BFS content and curing duration, as a result of the increased aluminium and silicon levels within the $\mathrm{C}-\mathrm{A}-\mathrm{S}-\mathrm{H} ; \mathrm{Ca} / \mathrm{Si}$ ratios calculated from Equation 16 of the paper of Richardson (2014) decreased with increased curing duration, whereas 
Table 5. Results of deconvolution of the ${ }^{29} \mathrm{Si}$ MAS NMR spectra as a function of time and cement composition

\begin{tabular}{|c|c|c|c|c|c|c|c|c|c|}
\hline $\begin{array}{l}\text { Sample BFS: } \\
\text { PC ratio }\end{array}$ & Curing time: $\mathbf{d}$ & $\mathrm{Q}^{0}$ & $Q^{1}(I)$ & $Q^{1}(I I)$ & $Q^{1}$ total & $Q^{2}(1 A l)$ & $Q^{2}$ & $Q^{3}(1 A l)$ & $Q^{3}$ \\
\hline \multirow[t]{5}{*}{$1: 1$} & 28 & $0 \cdot 17$ & $17 \cdot 9$ & $21 \cdot 8$ & $39 \cdot 6$ & $24 \cdot 1$ & $31 \cdot 7$ & $3 \cdot 2$ & $1 \cdot 2$ \\
\hline & 56 & 1.7 & $16 \cdot 1$ & 21.9 & 37.9 & $22 \cdot 2$ & $33 \cdot 4$ & $3 \cdot 7$ & $1 \cdot 1$ \\
\hline & 90 & 0.7 & 14.4 & $21 \cdot 8$ & $36 \cdot 2$ & $23 \cdot 2$ & $32 \cdot 6$ & $4 \cdot 7$ & 2.8 \\
\hline & 180 & $2 \cdot 2$ & $14 \cdot 4$ & $21 \cdot 8$ & $36 \cdot 2$ & $23 \cdot 2$ & $32 \cdot 6$ & $4 \cdot 7$ & $2 \cdot 8$ \\
\hline & 360 & $2 \cdot 4$ & $14 \cdot 8$ & $20 \cdot 4$ & $35 \cdot 2$ & $21 \cdot 7$ & $35 \cdot 8$ & $3 \cdot 8$ & $1 \cdot 1$ \\
\hline \multirow[t]{5}{*}{$3: 1$} & 28 & $0 \cdot 0$ & $10 \cdot 6$ & $21 \cdot 8$ & $32 \cdot 4$ & $30 \cdot 9$ & $34 \cdot 6$ & $1 \cdot 5$ & 0.7 \\
\hline & 56 & $0 \cdot 6$ & $9 \cdot 6$ & $23 \cdot 7$ & $33 \cdot 3$ & $28 \cdot 7$ & $35 \cdot 0$ & $2 \cdot 4$ & 0.0 \\
\hline & 90 & 0.9 & $9 \cdot 4$ & $22 \cdot 6$ & $32 \cdot 0$ & $27 \cdot 7$ & 37.0 & $2 \cdot 3$ & 0.0 \\
\hline & 180 & $4 \cdot 6$ & $11 \cdot 0$ & $21 \cdot 2$ & $32 \cdot 2$ & $28 \cdot 2$ & $32 \cdot 0$ & $3 \cdot 0$ & 0.0 \\
\hline & 360 & $4 \cdot 6$ & $9 \cdot 6$ & $20 \cdot 8$ & $30 \cdot 4$ & $27 \cdot 6$ & $33 \cdot 3$ & $3 \cdot 6$ & 0.7 \\
\hline \multirow[t]{5}{*}{ 9:1 } & 28 & 0.0 & $6 \cdot 4$ & $24 \cdot 5$ & $30 \cdot 9$ & $31 \cdot 2$ & $36 \cdot 6$ & $1 \cdot 2$ & 0.2 \\
\hline & 56 & $0 \cdot 0$ & $6 \cdot 0$ & $24 \cdot 0$ & $30 \cdot 0$ & $31 \cdot 0$ & $35 \cdot 8$ & $2 \cdot 2$ & $1 \cdot 2$ \\
\hline & 90 & $0 \cdot 0$ & $6 \cdot 8$ & $22 \cdot 1$ & 28.9 & $29 \cdot 9$ & $35 \cdot 5$ & $3 \cdot 4$ & $2 \cdot 3$ \\
\hline & 180 & $2 \cdot 8$ & $7 \cdot 8$ & $20 \cdot 1$ & $27 \cdot 9$ & $30 \cdot 6$ & $32 \cdot 6$ & $4 \cdot 5$ & $1 \cdot 6$ \\
\hline & 360 & $0 \cdot 3$ & $5 \cdot 6$ & $22 \cdot 3$ & $27 \cdot 8$ & $30 \cdot 8$ & $36 \cdot 2$ & $3 \cdot 1$ & 1.8 \\
\hline
\end{tabular}

Table 6. Summary of structural characteristics of the C-A-S-H gel forming in BFS:PC cements based on the ${ }^{29} \mathrm{Si}$ MAS NMR results

\begin{tabular}{|c|c|c|c|c|c|c|c|c|c|}
\hline \multirow[b]{2}{*}{ Time: d } & \multicolumn{3}{|c|}{$\mathrm{Al} / \mathrm{Si}$} & \multicolumn{3}{|c|}{$\mathrm{Ca} / \mathrm{Si}$} & \multicolumn{3}{|c|}{ Mean chain length (MCL) } \\
\hline & $1: 1$ & $3: 1$ & $9: 1$ & $1: 1$ & $3: 1$ & 9:1 & $1: 1$ & $3: 1$ & $9: 1$ \\
\hline 28 & 0.12 & 0.15 & $0 \cdot 16$ & $1 \cdot 13$ & 1.07 & 1.05 & $5 \cdot 64$ & $7 \cdot 13$ & 7.49 \\
\hline 56 & 0.11 & $0 \cdot 14$ & $0 \cdot 15$ & $1 \cdot 11$ & 1.07 & 1.05 & $5 \cdot 77$ & $6 \cdot 83$ & $7 \cdot 71$ \\
\hline 90 & $0 \cdot 12$ & $0 \cdot 14$ & $0 \cdot 15$ & $1 \cdot 11$ & 1.05 & 1.04 & $6 \cdot 14$ & $7 \cdot 06$ & $7 \cdot 95$ \\
\hline 180 & 0.12 & 0.15 & 0.16 & $1 \cdot 11$ & 1.08 & 1.05 & $6 \cdot 14$ & $6 \cdot 80$ & 8.07 \\
\hline 360 & $0 \cdot 11$ & 0.14 & $0 \cdot 15$ & 1.08 & 1.06 & 1.03 & $6 \cdot 16$ & $7 \cdot 19$ & $8 \cdot 27$ \\
\hline
\end{tabular}

aluminium/silicon ( $\mathrm{Al} / \mathrm{Si})$ (Equation 7) remained constant, consistent with the discussion presented above. Despite evidence of less cross-linking within the 3:1 system than the others, it still achieved a greater MCL because of the higher proportion of bridging sites when compared with the 1:1 system.
(TEM-EDX) or scanning electron microscopy energy dispersive X-ray spectroscopy (SEM-EDX) data are considered to provide more accurate results when considering the $\mathrm{Ca} / \mathrm{Si}$ values of $\mathrm{C}-\mathrm{A}-\mathrm{S}-\mathrm{H}$ gels in hydrated cementitious systems. The nature of the process of deconvoluting NMR spectra based on

6. $\mathrm{MCL}=\frac{2}{\left[\mathrm{Q}^{1} / \mathrm{Q}^{1}+\mathrm{Q}^{2}(0 \mathrm{Al})+\frac{3}{2} \mathrm{Q}^{2}(1 \mathrm{Al})+\mathrm{Q}^{3}(0 \mathrm{Al})+\mathrm{Q}^{3}(1 \mathrm{Al})\right]}$

7. $\frac{\mathrm{Al}}{\mathrm{Si}}=\frac{\frac{1}{2} \mathrm{Q}^{2}(1 \mathrm{Al})}{\mathrm{Q}^{1}+\mathrm{Q}^{2}(0 \mathrm{Al})+\mathrm{Q}^{2}(1 \mathrm{Al})+\mathrm{Q}^{3}(0 \mathrm{Al})+\mathrm{Q}^{3}(1 \mathrm{Al})}$

The $\mathrm{Ca} / \mathrm{Si}$ ratio of each grout calculated from this method was significantly lower than what has been observed in the literature for comparable cements (Richardson and Groves, 1992). Rarely has the $\mathrm{Ca} / \mathrm{Si}$ ratio been published when derived from ${ }^{29} \mathrm{Si}$ MAS NMR data of hydrated cementitious materials; however, the $\mathrm{Al} / \mathrm{Si}$ and $\mathrm{MCL}$ are often provided using this methodology (Andersen et al., 2003; Dai et al., 2014; Skibsted and Andersen, 2013; Sun et al., 2006). Generally, transmission electron microscopy energy dispersive X-ray spectroscopy the local environment of silicon contains many issues because of the wide variety of potential interaction ions that impact the chemical shift of each silicon species, specifically the dimer species $\left(Q^{1}\right)$, which would have the greatest impact on the $\mathrm{Ca} / \mathrm{Si}$ values. As a result of the high level of variation and overlapping signal of anhydrous material, a fully detailed structural model considering the $\mathrm{Ca} / \mathrm{Si}$ based on the site concentration values determined from NMR has yet to be created to convert this information into $\mathrm{Ca} / \mathrm{Si}$ values similar to those determined by more direct methods. Richardson (2014) provided an in-depth overview of how using different structural models influenced the $\mathrm{Ca} / \mathrm{Si}$ ratio determined using NMR data, and highlighted the variation in the possible results based on which model was used. It was concluded that the use of NMR data consistently yielded lower $\mathrm{Ca} / \mathrm{Si}$ values 
when compared to SEM or TEM results. Analysis using the cross-linked substituted tobermorite model (CSTM) method (Myers et al., 2013) provides good agreement for NMR data of alkali-activated slag systems, but its application here also tended to produce low $\mathrm{Ca} / \mathrm{Si}$ values. Despite these issues, NMR data can still supply useful information about the trend in $\mathrm{Ca} / \mathrm{Si}$ values based on the blend ratio and time of curing of the cement systems of interest in this study; the actual values should be treated as semi-quantitative rather than absolute.

\section{Determination of degree of hydration using ${ }^{29} \mathrm{Si}$ MAS NMR and selective dissolution}

As described in the earlier section entitled ${ }^{27} \mathrm{Al}$ and ${ }^{29} \mathrm{Si}$ MAS NMR', the fitted ${ }^{29} \mathrm{Si}$ MAS NMR spectra of the anhydrous materials were scaled and used as components in the deconvolution of the spectra of the reaction products, to determine the degree of hydration of each constituent within the hydrated samples. Comparison of the degree of hydration between the (independent) ${ }^{29} \mathrm{Si}$ MAS NMR and selective dissolution techniques for BFS, Figure 7, displays good agreement between the two techniques. The BFS in the $1: 1$ and 3:1 blends was slower to react when compared to some reports of other BFS: PC blended cements of the same proportions (AduAmankwah et al., 2017; Lumley et al., 1996), but does align better with various other reports in the literature (Durdziński et al., 2017a; Escalante et al., 2001; Snellings et al., 2014). This may be attributed to the rather lower $w / s$ ratio used here, which is based on the UK nuclear industry's specification for acceptance mixes (Angus et al., 2010; Utton et al., 2008).

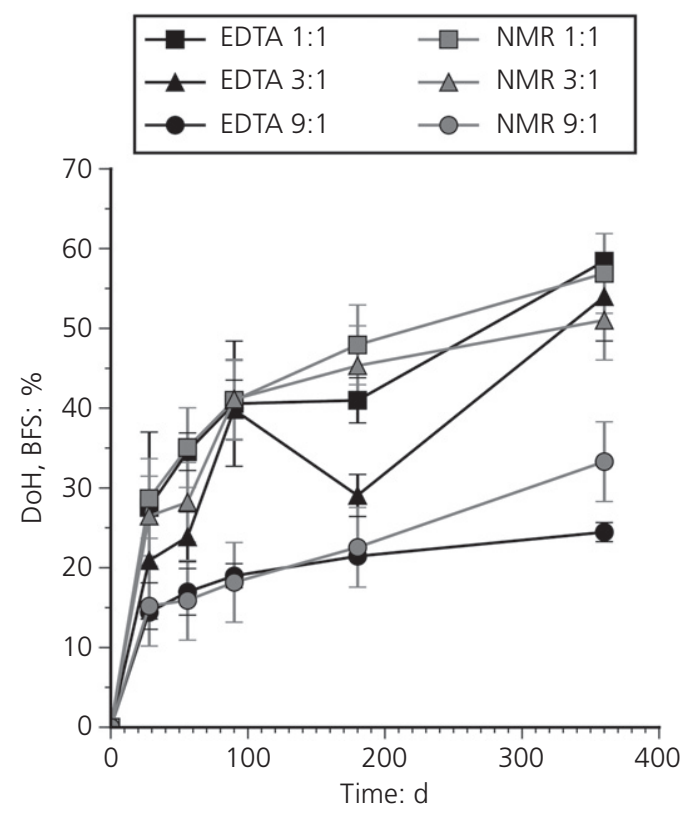

Figure 7. Degree of reaction of BFS within the different blend ratios, based on ${ }^{29} \mathrm{Si}$ NMR MAS deconvolutions (NMR) and on selective dissolution (EDTA)
Determination of the extent of reaction by NMR spectral deconvolution has an error margin of approximately $5 \%$, as previously discussed based on the relaxation delay (Poulsen et al., 2009; Skibsted et al., 1995), whereas the selective dissolution technique used here has reported errors of up to $10 \%$ (Mohan and Taylor, 1985), so these possible variations must also be considered when comparing the results reported here with those available in the literature. Higher slag inclusion would be expected to result in a lower degree of hydration of the slag, as there is less portlandite produced by PC hydration that would activate the latent hydraulic character of the slag, and this trend was borne out in the current results. After $360 \mathrm{~d}$ the 9:1 system had approximately half the degree of reaction of the $3: 1$, whereas the difference between $3: 1$ and $1: 1$ was less marked; both of these systems contained significant residual portlandite according to the XRD data in Figure 4, so this was evidently less of a limitation at slag contents of up to $75 \%$.

Across all blend ratios, the degree of alite hydration as determined by deconvolution of ${ }^{29} \mathrm{Si}$ MAS NMR spectra reached at least $79 \cdot 0 \%$ after $28 \mathrm{~d}$, but from this time up to $360 \mathrm{~d}$ there was only a small further increase (Figure 8). Higher BFS content led to a higher degree of hydration of the alite, possibly due to the higher water to alite ratio in the systems with higher BFS content, where the slower reaction of the slag means that more water and space are available for PC hydration in the early stages of the reaction process, in a form of the filler effect commonly seen in blended cements, but taken to an extreme case where the cement is only $10-25 \%$ PC.

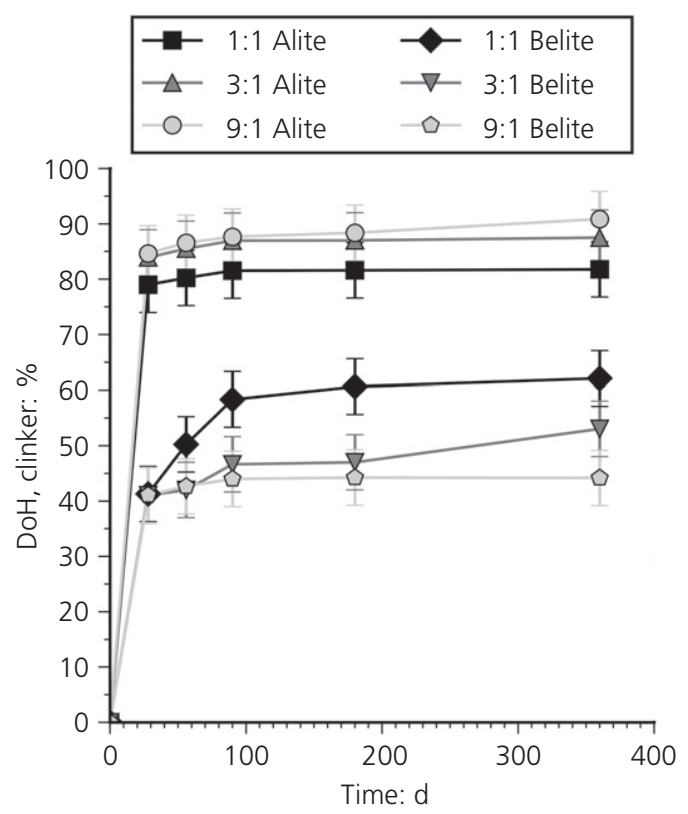

Figure 8. Degree of reaction of calcium silicate clinker phases (alite and belite) within the different blend ratios, based on ${ }^{29} \mathrm{Si}$ MAS NMR spectral deconvolutions 
A moderate degree of reaction of belite can be seen in all blends assessed, but not exceeding $65 \%$ even at $360 \mathrm{~d}$ in any of the cements evaluated; the belite in the 9:1 grout showed very little reaction beyond $90 \mathrm{~d}$. This may be because belite is more prone to react at higher $\mathrm{pH}$ (Kawabata et al., 2013), and the pore solution $\mathrm{pH}$ of BFS:PC cements is reduced when they contain very high fractions of BFS (Vollpracht et al., 2015).

\section{Thermodynamic modelling}

\section{Calculating the hydrate phase assemblage}

Using the degree of hydration data presented above, prediction of the phase assemblages by way of thermodynamic modelling (Figure 9) gave results that corresponded well with the phases identified experimentally.

As expected, the $\mathrm{C}-\mathrm{A}-\mathrm{S}-\mathrm{H}$ gel was dominant in all grouts, and was predicted to entirely consume portlandite by $28 \mathrm{~d}$ in the 9:1 system. The fact that this was not observed experimentally (i.e. a small quantity of portlandite persisted at all ages in Figure 4) may indicate spatial heterogeneity of the blended cement leading to deviations from the assumed equilibrium behaviour, as has been discussed recently by Skocek et al. (2017) for other low-clinker cements. Portlandite formation was much higher in the $1: 1$ cement $(14 \mathrm{wt} \%$ after $360 \mathrm{~d})$ than the $3: 1$ cement $(10 \mathrm{wt} \%$ after $360 \mathrm{~d})$, which corresponds well with the XRD data.

Ettringite appears in the model phase assemblages at early age for all blends assessed; however, in the 3:1 and 9:1 cements it was predicted to be replaced by monosulfate, after $60 \mathrm{~d}$ and $6 \mathrm{~d}$, respectively. From the experimental data presented above, only a small amount of ettringite was observed in the $3: 1$ system at $28 \mathrm{~d}$, and none from $56 \mathrm{~d}$ onwards, whereas no ettringite was observed in the 9:1 system. Ettringite was still predicted in the $1: 1$ system after $360 \mathrm{~d}$, along with increasing monosulfate as curing time and the degree of hydration of the BFS increased. It is possible that experimental factors not fully captured in the thermodynamic model - particularly the influence of sulfide provided by the slag, which can be incorporated into AFm phases (Nedyalkova et al., 2017) and/or oxidised to sulfate - will lead to under-prediction of the stability of ettringite in the model applied here. However, the predicted increase in monosulfate content in higher BFS cements did align well with the experimental data. It should also be noted that the TAH phase identified by NMR was not included within the thermodynamic database used in this work.

Hydrotalcite-group phase formation was predicted to increase with BFS content and degree of hydration of the slag; after $360 \mathrm{~d}$ hydrotalcite comprised as much as $12.6 \mathrm{wt} \%$ of the solid binder constituents in the 9:1 system. Thus, the peak at $11.6^{\circ}$ $2 \theta$ in Figure 4 is identified as mainly attributed to hydrotalcite formation. Figure 9 displays the reducing amount of monocarbonate forming when lower levels of PC are available in the

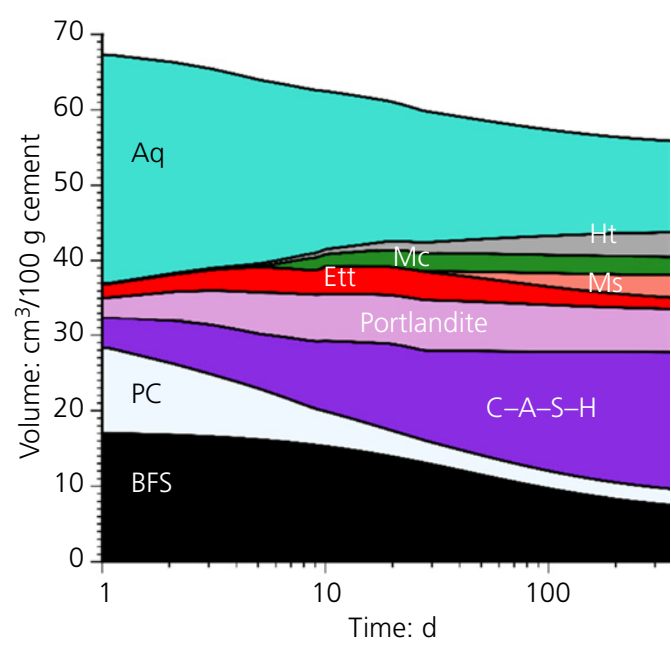

(a)

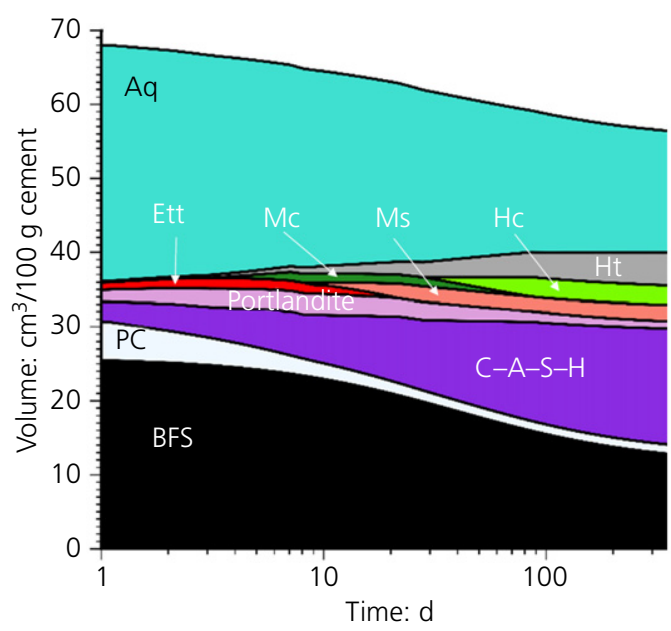

(b)

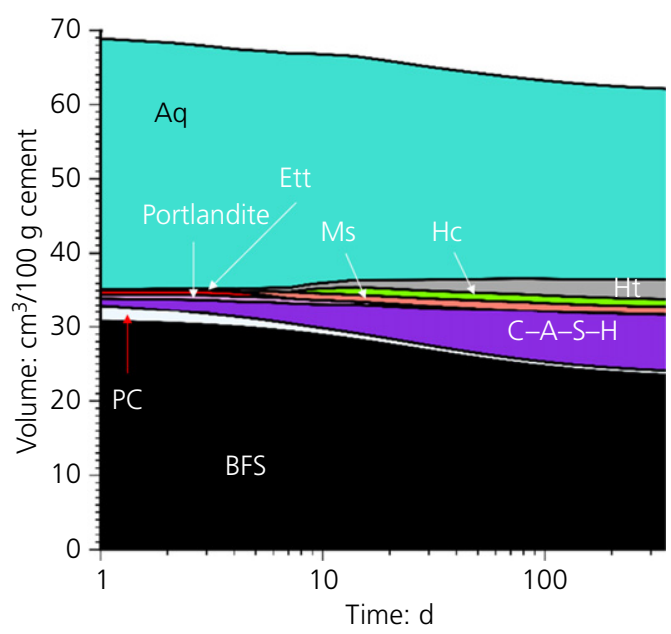

(c)

Figure 9. Hydrate phase assemblages predicted using thermodynamic modelling, for: (a) 1:1; (b) 3:1; (c) 9:1 grouts reacting at $35^{\circ} \mathrm{C}$, based on the experimentally determined (NMR) degree of hydration data up to $360 \mathrm{~d}$ (Aq, aqueous solution; $\mathrm{Mc}$, monocarbonate; Ht, hydrotalcite; Ms, monosulfate; Ett, ettringite) 
system to provide calcite. In the 3:1 and 9:1 systems, hemicarbonate becomes the dominant carbonate hydrate phase at later ages, rather than monocarbonate, as can be seen in the XRD results. Matschei et al. (2007a, 2007b) demonstrated that the lower amount of $\mathrm{CO}_{3}{ }^{2-}$ ions present in the pore solution causes this phase transition from monocarbonate to hemicarbonate.

\section{Comparison of C-A-S-H gel structural characteristics between model and experiment}

The use of the high-Ca/Si end-members in the model may be the cause of the under-prediction of portlandite formation in the 9:1 system. The $\mathrm{Ca} / \mathrm{Si}$ ratio of $\mathrm{C}-\mathrm{A}-\mathrm{S}-\mathrm{H}$ in the modelled 9:1 system after $360 \mathrm{~d}$ was 1.373 (Table 7), which is higher than the 1.03 determined from the NMR spectra here (Table 6), but more similar to the value published by Richardson and Groves for a 9:1 cement also based on UK nuclear industry-specification materials, which was 1.29 (Richardson and Groves, 1992). There was a better agreement for the 3:1 system as it was closer to the value expected from literature data, $\mathrm{Ca} / \mathrm{Si}$ between 1.34 and 1.40 (Richardson and Groves, 1992). In the $3: 1$ and $9: 1$ systems, the $\mathrm{Ca} / \mathrm{Si}$ ratio decreases as $\mathrm{A} 1 / \mathrm{Si}$ increases. As expected, the $\mathrm{Ca} / \mathrm{Si}$ ratio in the $\mathrm{C}-\mathrm{A}-\mathrm{S}-\mathrm{H}$ is highest in the $1: 1$ formulation but, using this model, it was only marginally higher than the 3:1 after $360 \mathrm{~d}$.

Only the 1:1 system shows no alteration of the calculated C-A-S-H molar ratios with time, consistent with the NMR results (Table 6) which showed minimal variation. Under-prediction of the $\mathrm{Ca} / \mathrm{Si}$ in the $1: 1$ system corresponds to the overprediction of $\mathrm{Al} / \mathrm{Si}$ within the $\mathrm{C}-\mathrm{A}-\mathrm{S}-\mathrm{H}$ gel. Another limitation is that once the $\mathrm{Ca} / \mathrm{Si}$ ratio of the $\mathrm{C}-\mathrm{A}-\mathrm{S}-\mathrm{H}$ gel reaches $1 \cdot 4$ to $1 \cdot 5$, portlandite formation is more favourable than incorporating more calcium within the $\mathrm{C}-\mathrm{S}-\mathrm{H}$ gel, which limits the $\mathrm{Ca} / \mathrm{Si}$ ratio to this range.

As a result of the minimum $\mathrm{Ca} / \mathrm{Si}$ of $\mathrm{C}-\mathrm{A}-\mathrm{S}-\mathrm{H}$ formation required before portlandite can be formed, no portlandite was observed in the simulated 9:1 system, despite the fact that portlandite was observed in the X-ray diffractograms up to $360 \mathrm{~d}$. This issue was highlighted in the creation of the CSHQ model whereby, once the $\mathrm{C}-\mathrm{S}-\mathrm{H}$ reached a $\mathrm{Ca} / \mathrm{Si}$ ratio of $1 \cdot 5$, portlandite would begin to form alongside the $\mathrm{C}-\mathrm{S}-\mathrm{H}$ (Kulik, 2011).
However, a promising trend in the model results is that, with higher levels of slag hydration, the $\mathrm{Ca} / \mathrm{Si}$ value decreases and the $\mathrm{Al} / \mathrm{Si}$ value increases, as was seen in the NMR results. Over-prediction of the MCL within the 1:1 grout occurs owing to the poor agreement of the $\mathrm{Ca} / \mathrm{Si}$ and $\mathrm{Al} / \mathrm{Si}$ values; however, the 3:1 and 9:1 systems display better agreement despite the differences between predicted and experimental $\mathrm{Ca} / \mathrm{Si}$ ratios.

\section{Modelling of aged BFS:PC cements}

The applicability of this method to samples cured for more extended durations than those evaluated in this study is of critical importance when applying this method to long-term storage or disposal of wastes. Here the thermodynamic modelling approach described in the earlier section 'Thermodynamic modelling method' is applied for modelling 20 year old BFS: PC samples, whose detailed characterisation was carried out by Taylor et al. (2010). The phase assemblage predictions show good agreement with the identified hydration products forming in the aged cements (Figure 10). The dominant phases at later age are hydrotalcite and $\mathrm{C}-\mathrm{A}-\mathrm{S}-\mathrm{H}$ gel, and the good agreement regarding portlandite content is particularly notable (Table 8).

At advanced curing ages the end-member model used in this study for blended cements was struggling with the same issues as the earlier age samples in the section 'Comparison of $\mathrm{C}-\mathrm{A}-\mathrm{S}-\mathrm{H}$ gel structural characteristics between model and experiment', whereby the $\mathrm{C}-\mathrm{A}-\mathrm{S}-\mathrm{H}$ gel required a certain $\mathrm{Ca} / \mathrm{Si}$ ratio before portlandite could form. This has led to an over-prediction of the $\mathrm{Ca} / \mathrm{Si}$ ratio of the $\mathrm{C}-\mathrm{A}-\mathrm{S}-\mathrm{H}$ gel (Table 9) and no predicted portlandite formation in the 9:1 system. There was a greater variation of the $\mathrm{Ca} / \mathrm{Si}$ ratio in the 9:1 system when compared to the $1: 1$ and $3: 1$ systems, due to the much lower amount of calcium available for reaction.

Under-prediction of the $\mathrm{Al} / \mathrm{Si}$ ratio was not as severe as the over-prediction of the $\mathrm{Ca} / \mathrm{Si}$ ratio. There was a small increase in $\mathrm{Al} / \mathrm{Si}$ as BFS replacement increased. Based on the geochemical equilibrium calculations that govern the software, the bulk $\mathrm{Ca} / \mathrm{Si}$ and $\mathrm{Al} / \mathrm{Si}$ ratios govern the performance of the $\mathrm{C}-\mathrm{A}-\mathrm{S}$ $\mathrm{H}$ end-member model. As similar levels of bulk $\mathrm{Al} / \mathrm{Si}$ were observed in each system (approximate $\mathrm{Al} / \mathrm{Si}=0 \cdot 35$ ), there was little variation in the $\mathrm{Al} / \mathrm{Si}$ ratio of the $\mathrm{C}-\mathrm{A}-\mathrm{S}-\mathrm{H}$ (which is

Table 7. Summary of structural characteristics of the $\mathrm{C}-\mathrm{A}-\mathrm{S}-\mathrm{H}$ gel derived from thermodynamic modelling

\begin{tabular}{|c|c|c|c|c|c|c|c|c|c|}
\hline \multirow[b]{2}{*}{ Time: d } & \multicolumn{3}{|c|}{$\mathrm{Al} / \mathrm{Si}$} & \multicolumn{3}{|c|}{$\mathrm{Ca} / \mathrm{Si}$} & \multicolumn{3}{|c|}{ MCL } \\
\hline & $1: 1$ & $3: 1$ & $9: 1$ & $1: 1$ & $3: 1$ & $9: 1$ & $1: 1$ & $3: 1$ & 9:1 \\
\hline 28 & 0.137 & $0 \cdot 135$ & $0 \cdot 156$ & 1.424 & 1.427 & 1.408 & $7 \cdot 234$ & $7 \cdot 204$ & $7 \cdot 494$ \\
\hline 56 & 0.137 & 0.136 & $0 \cdot 161$ & 1.424 & 1.430 & 1.404 & $7 \cdot 234$ & $7 \cdot 206$ & $7 \cdot 496$ \\
\hline 90 & 0.137 & $0 \cdot 140$ & $0 \cdot 161$ & 1.424 & 1.424 & 1.403 & $7 \cdot 232$ & $7 \cdot 260$ & $7 \cdot 576$ \\
\hline 180 & 0.137 & $0 \cdot 144$ & $0 \cdot 162$ & 1.424 & 1.420 & $1 \cdot 384$ & $7 \cdot 232$ & $7 \cdot 320$ & $7 \cdot 754$ \\
\hline 360 & 0.137 & $0 \cdot 144$ & $0 \cdot 163$ & 1.424 & 1.419 & $1 \cdot 373$ & $7 \cdot 232$ & $7 \cdot 320$ & $7 \cdot 860$ \\
\hline
\end{tabular}




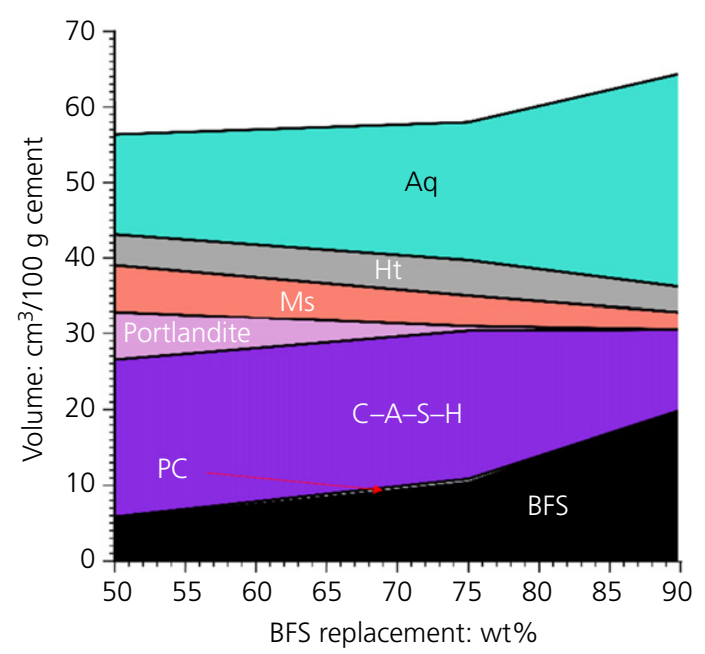

Figure 10. Calculated phase assemblage of BFS:PC cements using the degree of hydration and precursor materials reported by Taylor et al. (2010) (Aq, aqueous solution; Ht, hydrotalcite; Ms, monosulfate)

Table 8. Portlandite content, as weight percentage of the hydrates formed at varying degrees of slag replacement

\begin{tabular}{lcc|}
$\begin{array}{lcc}\text { BFS:PC blend } \\
\text { ratio }\end{array}$ & \multicolumn{2}{c}{ Portlandite in phase assemblage: \% } \\
\cline { 2 - 3 } & 20 year sample & GEMS \\
\hline $1: 1$ & 10 & 14 \\
$3: 1$ & 3 & 2 \\
$9: 1$ & 1 & 0 \\
\hline
\end{tabular}

Results from 20 year sample are from Taylor et al. (2010)

Table 9. Structural characteristics of the C-A-S-H gel of the 20 year old sample analysed by Taylor et al. (2010) and thermodynamic modelling (GEMS) for these systems

\begin{tabular}{|c|c|c|c|c|c|c|}
\hline \multirow[b]{2}{*}{$\begin{array}{l}\text { BFS:PC } \\
\text { blend ratio }\end{array}$} & \multicolumn{2}{|c|}{$\mathrm{Al} / \mathrm{Si}$} & \multicolumn{2}{|c|}{$\mathrm{Ca} / \mathrm{Si}$} & \multicolumn{2}{|c|}{ MCL } \\
\hline & $\begin{array}{c}20 \\
\text { year }\end{array}$ & GEMS & $\begin{array}{c}20 \\
\text { year }\end{array}$ & GEMS & $\begin{array}{c}20 \\
\text { year }\end{array}$ & GEMS \\
\hline 1:1 & 0.14 & 0.14 & $1 \cdot 32$ & 1.43 & 13.8 & $8 \cdot 2$ \\
\hline $3: 1$ & 0.16 & 0.14 & $1 \cdot 31$ & 1.43 & $16 \cdot 1$ & $8 \cdot 2$ \\
\hline $9: 1$ & 0.18 & 0.15 & $1 \cdot 18$ & $1 \cdot 30$ & 14.3 & $9 \cdot 5$ \\
\hline
\end{tabular}

limited in the model by the allowable degree of incorporation of $\mathrm{Al}$ into $\mathrm{Si}$ sites in the tobermorite structure); however, the $\mathrm{Ca} / \mathrm{Si}$ ratio was much lower within the 9:1 system which caused the greater variation as a function of age. Following the experimental results, the later age samples had a larger MCL than the earlier age samples modelled. Values from the modelling work were significantly lower than those observed experimentally; however, the clear increase of MCL in all grouts when compared to the earlier age samples does indicate reasonable applicability of the model to later age cements.

\section{Conclusions}

Prediction of cement hydrate phase assemblages using thermodynamic modelling is fundamentally dependent on the availability of a complete and accurate database for all phases present, and this work has demonstrated that this still poses some challenges in the description of BFS-PC blends at high BFS content. Qualitatively, good agreement of the predicted phase assemblage can be observed for the 1 year cured cement systems between the NMR and XRD results. All the main phases observed experimentally were present in the simulated phase assemblages, and in comparable proportions at each age of curing. This agreement highlights the potential of using ${ }^{29} \mathrm{Si}$ MAS NMR with careful spectral deconvolution for determination of the degree of hydration for silicon-containing cement constituents.

The calculation of structural characteristics of the $\mathrm{C}-\mathrm{A}-\mathrm{S}-\mathrm{H}$ gel using a thermodynamic modelling approach still has limitations; however, it is promising that the trend of $\mathrm{Ca} / \mathrm{Si}, \mathrm{Al} / \mathrm{Si}$ and MCL follows what is observed from experimental results. The end-member compositions and energetics of the C-A-S$\mathrm{H}$ gel still require refinement, possibly including introduction of alkali-containing end-members and/or the incorporation of aluminium into interlayer sites. Improvement of the aqueous solution modelling approach may also be a method of improving the structural accuracy of the solid solution phases within blended cements. Methods such as the specific ion interaction theory or Pitzer models may lead to an improved ability to predict the phase assemblages of these complex systems. Introducing these methods will also allow a greater level of accuracy when combining this method for predicting interactions of cements with wastes.

\section{Acknowledgements}

This work was funded by the Engineering and Physical Sciences Research Council (EPSRC) UK in partnership with the National Nuclear Laboratory, through the iCASE scheme. This research was performed in part at the MIDAS Facility, at the University of Sheffield, which was established with support from the UK Department of Energy and Climate Change. The NMR spectra were collected using the EPSRC UK national solid-state NMR service at Durham University. The authors would like to thank Shishir Mundra, Sam Walling, Brant Walkley and James Vigor for their helpful advice and discussion when performing data analysis.

\section{REFERENCES}

Adu-Amankwah S, Zajac M, Stabler C, Lothenbach B and Black L (2017) Influence of limestone on the hydration of ternary slag cements. Cement and Concrete Research 100: 96-109, https://doi.org/ 10.1016/j.cemconcomp.2013.11.007.

Andersen MD, Jakobsen HJ and Skibsted J (2003) Incorporation of aluminum in the calcium silicate hydrate $(\mathrm{C}-\mathrm{S}-\mathrm{H})$ of hydrated Portland cements: a high-field ${ }^{27} \mathrm{Al}$ and ${ }^{29} \mathrm{Si}$ MAS NMR investigation. Inorganic Chemistry 42(7): 2280-2287. 
Andersen MD, Jakobsen HJ and Skibsted J (2006) A new aluminiumhydrate species in hydrated Portland cements characterized by ${ }^{27} \mathrm{Al}$ and ${ }^{29} \mathrm{Si}$ MAS NMR spectroscopy. Cement and Concrete Research 36(1): 3-17.

Angus MJ, Godfrey IH, Hayes M and Foster S (2010) Managing change in the supply of cement powders for radioactive waste encapsulation - twenty years of operational experience. Proceedings of WM2010 Conference, Phoenix, AZ, USA. WM Symposia, Inc., Tempe, AZ, USA.

Appelo CAJ and Postma D (2005) Geochemistry, Groundwater and Pollution. CRC Press, Boca Raton, FL, USA.

Atkins M and Glasser FP (1992) Application of Portland cement-based materials to radioactive waste immobilization. Waste Management 12(2-3): 105-131.

Bernal SA, Provis JL, Walkley B et al. (2013) Gel nanostructure in alkaliactivated binders based on slag and fly ash, and effects of accelerated carbonation. Cement and Concrete Research 53 127-144, https://doi.org/10.1016/j.cemconres.2013.06.007.

Bernal SA, San Nicolas R, Myers RJ et al. (2014) MgO content of slag controls phase evolution and structural changes induced by accelerated carbonation in alkali-activated binders. Cement and Concrete Research 57: 33-43, https://doi.org/10.1016/j.cemconres. 2013.12.003.

Bland CH and Sharp JH (1991) A conduction calorimetric study of gasifier slag-Portland cement blends. Cement and Concrete Research 21(2-3): 359-367.

Brunet F, Charpentier T, Chao CN, Peycelon H and Nonat A (2010) Characterization by solid-state NMR and selective dissolution techniques of anhydrous and hydrated CEM V cement pastes. Cement and Concrete Research 40(2): 208-219.

Cau Dit Coumes C, Courtois S, Peysson S, Ambroise J and Pera J (2009) Calcium sulfoaluminate cement blended with OPC: a potential binder to encapsulate low-level radioactive slurries of complex chemistry. Cement and Concrete Research 39(9): $740-747$.

Clark BA and Brown P (1999) The formation of calcium sulfoaluminate hydrate compounds: part I. Cement and Concrete Research 29(12): 1943-1948.

Collier NC and Milestone NB (2010) The encapsulation of $\mathrm{Mg}(\mathrm{OH})_{2}$ sludge in composite cement. Cement and Concrete Research 40(3): $452-459$

Dai Z, Tran TT and Skibsted J (2014) Aluminum incorporation in the $\mathrm{C}-\mathrm{S}-\mathrm{H}$ phase of white Portland cement-metakaolin blends studied by ${ }^{27} \mathrm{Al}$ and ${ }^{29} \mathrm{Si}$ MAS NMR spectroscopy. Journal of the American Ceramic Society 97(8): 2662-2671.

Damidot D, Lothenbach B, Herfort D and Glasser FP (2011) Thermodynamics and cement science. Cement and Concrete Research 41(7): 679-695.

Deschner F, Lothenbach B, Winnefeld F and Neubauer J (2013) Effect of temperature on the hydration of Portland cement blended with siliceous fly ash. Cement and Concrete Research 52: 169-181, https://doi.org/10.1016/j.cemconres.2013.07.006.

Durdziński PT, Ben Haha M, Bernal SA et al. (2017a) Outcomes of the RILEM round robin on degree of reaction of slag and fly ash in blended cements. Materials and Structures 50(2): 135.

Durdziński PT, Ben Haha M, Zajac M and Scrivener KL (2017b) Phase assemblage of composite cements. Cement and Concrete Research 99: 172-182, https://doi.org/10.1016/j.cemconres.2017.05.009.

Dyson HM, Richardson IG and Brough AR (2007) A combined ${ }^{29} \mathrm{Si}$ MAS NMR and selective dissolution technique for the quantitative evaluation of hydrated blast furnace slag cement blends. Journal of the American Ceramic Society 90(2): 598-602.

Edwards CL, Alemany LB and Barron AR (2007) Solid-state ${ }^{29} \mathrm{Si}$ NMR analysis of cements: comparing different methods of relaxation analysis for determining spin-lattice relaxation times to enable determination of the $\mathrm{C}_{3} \mathrm{~S} / \mathrm{C}_{2} \mathrm{~S}$ ratio. Industrial and Engineering Chemistry Research 46(15): 5122-5130.

Elakneswaran Y, Owaki E, Miyahara S et al. (2016) Hydration study of slag-blended cement based on thermodynamic considerations. Construction and Building Materials 124: 615-625, https://doi.org/ 10.1016/j.conbuildmat.2016.07.138.

Escalante Jl, Gómez L, Johal KK et al. (2001) Reactivity of blast-furnace slag in Portland cement blends hydrated under different conditions. Cement and Concrete Research 31(10): 1403-1409.

Escalante-García Jl and Sharp JH (1998) Effect of temperature on the hydration of the main clinker phases in Portland cements: part II, blended cements. Cement and Concrete Research 28(9): 1245-1257.

Escalante-García Jl and Sharp JH (2004) The chemical composition and microstructure of hydration products in blended cements. Cememt and Concrete Composites 26: 967-976, https://doi.org/10.1016/ j.cemconcomp.2004.02.036

Faucon P, Delagrave A, Petit JC et al. (1999) Aluminum incorporation in calcium silicate hydrates $(\mathrm{C}-\mathrm{S}-\mathrm{H})$ depending on their $\mathrm{Ca} / \mathrm{Si}$ ratio. Journal of Physical Chemistry B 103(37): 7796-7802.

Gastuche MC, Brown G and Mortland MM (1967) Mixed magnesiumaluminium hydroxides. Clay Minerals 7(2): 193-201.

Glasser FP (1992) Progress in the immobilization of radioactive wastes in cement. Cement and Concrete Research 22(2-3): 201-216.

Gougar MLD, Scheetz BE and Roy DM (1996) Ettringite and C-S-H Portland cement phases for waste ion immobilization: A review. Waste Management 16(4): 295-303.

Helgeson HC, Kirkham DH and Flowers GC (1981) Theoretical prediction of the thermodynamic behavior of aqueous electrolytes by high pressures and temperatures, IV; calculation of activity coefficients, osmotic coefficients, and apparent molal and standard relative partial molal properties to $600^{\circ} \mathrm{C}$ and $5 \mathrm{~kb}$. American Journal of Science 281: 1249-1516, https://doi.org/10.2475/ ajs. 281.10 .1249

Hill J and Sharp JH (2002) The mineralogy and microstructure of three composite cements with high replacement levels. Cement and Concrete Composites 24(2): 191-199.

Ismail I, Bernal SA, Provis JL, Hamdan S and Van Deventer JSJ (2013) Drying-induced changes in the structure of alkali-activated pastes. Journal of Materials Science 48(9): 3566-3577.

Kawabata Y and Yamada K (2015) Evaluation of alkalinity of pore solution based on the phase composition of cement hydrates with supplementary cementitious materials and its relation to suppressing ASR expansion. Journal of Advanced Concrete Technology 13(11): 538-553.

Ke X, Bernal SA and Provis JL (2016) Controlling the reaction kinetics of sodium carbonate-activated slag cements using calcined layered double hydroxides. Cement and Concrete Research 81: 24-37, https://doi.org/10.1016/j.cemconres.2015.11.012.

Ke X, Bernal SA and Provis JL (2017) Uptake of chloride and carbonate by $\mathrm{Mg}-\mathrm{Al}$ and $\mathrm{Ca}-\mathrm{Al}$ layered double hydroxides in simulated pore solutions of alkali-activated slag cement. Cement and Concrete Research 100: 1-13, https://doi.org/10.1016/j.cemconres 2017.05 .015

Kocaba V (2009) Development and Evaluation of Methods to Follow Microstructural Development of Cementitious Systems Including Slags. PhD thesis, EPFL, Lausanne, Switzerland.

Kulik DA (2011) Improving the structural consistency of C-S-H solid solution thermodynamic models. Cement and Concrete Research 41(5): 477-495.

Kulik DA, Wagner T, Dmytrieva SV et al. (2013) GEM-Selektor geochemical modeling package: revised algorithm and GEMS3K numerical kernel for coupled simulation codes. Computational Geosciences 17(1): 1-24.

L'Hôpital E, Lothenbach B, Le Saout G, Kulik DA and Scrivener K (2015) Incorporation of aluminium in calcium-silicate-hydrates. 
Cement and Concrete Research 75: 91-103, https://doi.org/10.1016/ j.cemconres.2015.04.007.

L'Hôpital E, Lothenbach B, Kulik DA and Scrivener K (2016a) Influence of calcium to silica ratio on aluminium uptake in calcium silicate hydrate. Cement and Concrete Research 85: 111-121, https://doi.org/10.1016/j.cemconres.2016.01.014.

L'Hôpital E, Lothenbach B, Scrivener K and Kulik DA (2016b) Alkali uptake in calcium alumina silicate hydrate $(\mathrm{C}-\mathrm{A}-\mathrm{S}-\mathrm{H})$. Cement and Concrete Research 85: 122-136, https://doi.org/10.1016/ j.cemconres.2016.03.009.

Lothenbach B (2010) Thermodynamic equilibrium calculations in cementitious systems. Materials and Structures 43(10): 1413-1433. Lothenbach B and Winnefeld F (2006) Thermodynamic modelling of the hydration of Portland cement. Cement and Concrete Research 36(2): 209-226

Lothenbach B, Matschei T, Möschner G and Glasser FP (2008) Thermodynamic modelling of the effect of temperature on the hydration and porosity of Portland cement. Cement and Concrete Research 38(1): 1-18

Luke K and Glasser FP (1987) Selective dissolution of hydrated blast furnace slag cements. Cement and Concrete Research 17(2): 273-282.

Luke $\mathrm{K}$ and Lachowski E (2008) Internal composition of 20-year-old fly ash and slag-blended ordinary Portland cement pastes. Journal of the American Ceramic Society 91(12): 4084- 4092.

Lumley JS, Gollop RS, Moir GK and Taylor HFW (1996) Degrees of reaction of the slag in some blends with Portland cements. Cement and Concrete Research 26(1): 139-151.

Matschei T, Lothenbach B and Glasser FP (2007a) The role of calcium carbonate in cement hydration. Cement and Concrete Research 37(4): 551-558

Matschei T, Lothenbach B and Glasser FP (2007b) The AFm phase in Portland cement. Cement and Concrete Research 37(2): 118-130.

Mobasher N, Kinoshita H, Bernal SA and Sharrard CA (2014) $\mathrm{Ba}(\mathrm{OH})_{2}-$ blast furnace slag composite binders for encapsulation of sulphate bearing nuclear waste. Advances in Applied Ceramics 113(8) 460-465.

Mohan K and Taylor HFW (1985) Analytical study of pure and extended Portland cement pastes : I, pure Portland cement pastes. Journal of the American Ceramic Society 68(12): 685-690.

Moranville-Regourd M (2003) Cements made from blastfurnace slag. In Lea's Chemistry of Cement and Concrete, 4th edn (Hewlett PC (ed.)). Elsevier, Amsterdam, the Netherlands, pp. 637-678.

Myers RJ, Bernal SA, San Nicolas R and Provis JL (2013) Generalized structural description of calcium-sodium aluminosilicate hydrate gels: the cross-linked substituted tobermorite model. Langmuir 29(17): 5294-5306.

Myers RJ, Bernal SA and Provis JL (2014) A thermodynamic model for C-(N-)A-S-H gel: CNASH_ss. derivation and validation. Cement and Concrete Research 66: 27-47, https://doi.org/10.1016/ j.cemconres.2014.07.005.

Myers RJ, Bernal SA, Gehman JD, Van Deventer JSJ and Provis JL (2015a) The role of $\mathrm{Al}$ in cross-linking of alkali-activated slag cements. Journal of the American Ceramic Society 98(3): 996-1004.

Myers RJ, L'Hôpital E, Provis JL and Lothenbach B (2015b) Effect of temperature and aluminium on calcium (alumino)silicate hydrate chemistry under equilibrium conditions. Cement and Concrete Research 68: 83-93, https://doi.org/10.1016/j.cemconres. 2014.10.015.

Myers RJ, Lothenbach B, Bernal SA and Provis JL (2015c) Thermodynamic modelling of alkali-activated slag-based cements. Applied Geochemistry 61: 233-247, https://doi.org/10.1016/j.apgeochem. 2015.06.006.

NDA (Nuclear Decommissioning Authority) (2017) Radioactive Wastes in the UK: Summary of Data for International Reporting 2016. NDA, London, UK.
Nedyalkova L, Lothenbach B, Tits J, Wieland E and Mäder U (2017) Effect of redox conditions on sulfur and selenium binding in AFm phases. Goldschmidt Abstracts no. 2886, Paris, France. European Association of Geochemistry, Houten, the Netherlands.

Ojovan MI and Lee WE (2006) An Introduction to Nuclear Waste Immobilisation. Elsevier, Amsterdam, the Netherlands.

Pardal X, Brunet F, Charpentier T, Pochard I and Nonat A (2012) ${ }^{27} \mathrm{Al}$ and ${ }^{29} \mathrm{Si}$ solid-state NMR characterization of calcium-aluminosilicatehydrate. Inorganic Chemistry 51(3): 1827-1836.

Parkhurst DL and Appelo CAJ (2013) Description of Input and Examples for PHREEQC Version 3 - A Computer Program for Speciation, Batch-Reaction, One-Dimensional Transport, and Inverse Geochemical Calculations. U.S. Geological Survey Techniques and Methods, Denver, CO, USA.

Pausch I, Lohse HH, Schürmann K and Allmann R (1986) Syntheses of disordered and Al-rich hydrotalcite-like compounds. Clays and Clay Minerals 34(5): 507-510.

Poulsen SL, Kocaba V, Le Saoût G et al. (2009) Improved quantification of alite and belite in anhydrous Portland cements by ${ }^{29} \mathrm{Si}$ MAS NMR: effects of paramagnetic ions. Solid State Nuclear Magnetic Resonance 36(1): 32-44.

Provis JL and Bernal SA (2014) Geopolymers and related alkali-activated materials. Annual Review of Materials Research 44: 299-327, https://doi.org/10.1146/annurev-matsci-070813-113515.

Richardson IG (2013) The importance of proper crystal-chemical and geometrical reasoning demonstrated using layered single and double hydroxides. Acta Crystallographica B 69: 150-162, https://doi.org/10.1107/S205251921300376X.

Richardson IG (2014) Model structures for C-(A)-S-H. Acta Crystallographica B 70: 903-923, https://doi.org/10.1107/ S2052520614021982.

Richardson IG and Groves GW (1992) Microstructure and microanalysis of hardened cement pastes involving ground granulated blastfurnace slag. Journal of Materials Science 27(22): 6204-6212.

Richardson IG and Groves GW (1993) The incorporation of minor and trace elements into calcium silicate hydrate $(\mathrm{C}-\mathrm{S}-\mathrm{H})$ gel in hardened cement pastes. Cement and Concrete Research 23(1): 131-138.

Richardson IG and Groves GW (1997) The structure of the calcium silicate hydrate phases present in hardened pastes of white Portland cement/blast-furnace slag blends. Journal of Materials Science 32(18): 4793-4802.

Richardson IG, Brough AR, Brydson R, Groves GW and Dobson CM (1993) Location of aluminum in substituted calcium silicate hydrate $(\mathrm{C}-\mathrm{S}-\mathrm{H})$ gels as determined by ${ }^{29} \mathrm{Si}$ and ${ }^{27} \mathrm{Al} \mathrm{NMR}$ and EELS. Journal of the American Ceramic Society 76(9): 2285-2288.

Richardson IG, Brough AR, Groves GW and Dobson CM (1994) The characterization of hardened alkali-activated blast-furnace slag pastes and the nature of the calcium silicate hydrate $(\mathrm{C}-\mathrm{S}-\mathrm{H})$ phase. Cement and Concrete Research 24(5): 813-829.

Schöler A, Lothenbach B, Winnefeld F and Zajac M (2015) Hydration of quaternary Portland cement blends containing blast-furnace slag, siliceous fly ash and limestone powder. Cement and Concrete Composites 55: 374-382, https://doi.org/10.1016/j.cemconcomp. 2014.10.001.

Sharp JH, Hill J, Milestone NB and Miller EW (2003) Cementitious systems for encapsulation of intermediate level waste. In Proceedings of ICEM '03: The 9th International Conference on Environmental Remediation and Radioactive Waste Management, Oxford, UK (Benda G and Sheil F (eds)). American Society of Mechanical Engineers, New York, NY, USA, pp. 1-10.

Skibsted J and Andersen MD (2013) The effect of alkali ions on the incorporation of aluminum in the calcium silicate hydrate 
(C-S-H) phase resulting from Portland cement hydration studied by ${ }^{29} \mathrm{Si}$ MAS NMR. Journal of the American Ceramic Society 96(2): 651-656.

Skibsted J, Jakobsen HJ and Hall C (1995) Quantification of calcium silicate phases in Portland cements by ${ }^{29} \mathrm{Si}$ MAS NMR spectroscopy. Journal of the Chemical Society - Faraday Transactions 91(24): 4423-4430.

Skocek J, Zajac M, Stabler C and Ben Haha M (2017) Predictive modelling of hydration and mechanical performance of low Ca composite cements: Possibilities and limitations from industrial perspective. Cement and Concrete Research 100: 68-83, https://doi.org/10.1016/j.cemconres.2017.05.020.

Snellings R, Salze A and Scrivener KL (2014) Use of X-ray diffraction to quantify amorphous supplementary cementitious materials in anhydrous and hydrated blended cements. Cement and Concrete Research 64: 89-98, https://doi.org/110.1016/j.cemconres. 2014.06.011.

Sun GK, Young JF and Kirkpatrick RJ (2006) The role of $\mathrm{Al}$ in C-S-H: NMR, XRD, and compositional results for precipitated samples. Cement and Concrete Research 36(1): 18-29.

Taylor HFW (1989) Modification of the Bogue calculation. Advances in Cement Research 2(6): 73-77, http://dx.doi.org/10.1680/ adcr.1989.2.6.73
Taylor HFW (1990) Cement Chemistry, 2nd edn. Thomas Telford Services Ltd, London, UK.

Taylor R, Richardson IG and Brydson RMD (2010) Composition and microstructure of 20-year-old ordinary Portland cement-ground granulated blast-furnace slag blends containing 0 to $100 \%$ slag. Cement and Concrete Research 40(7): 971-983.

Utton CA, Hayes M, Hill J, Milestone NB and Sharp JH (2008) Effect of temperatures up to $90^{\circ} \mathrm{C}$ on the early hydration of Portland-blastfurnace slag cements. Journal of the American Ceramic Society 91(3): 948-954.

Vollpracht A, Lothenbach B, Snellings R and Haufe J (2015) The pore solution of blended cements: a review. Materials and Structures 49(8): 3341-3367.

Wagner T, Kulik DA, Hingerl FF and Dmytrievava SV (2012) Gem-Selektor geochemical modeling package: TSolMod library and data interface for multicomponent phase models. Canadian Mineralogist 50(5): 1173-1195.

Walker CS, Sutou S, Oda C, Mihara M and Honda A (2016) Calcium silicate hydrate $(\mathrm{C}-\mathrm{S}-\mathrm{H})$ gel solubility data and a discrete solid phase model at $25^{\circ} \mathrm{C}$ based on two binary non-ideal solid solutions. Cement and Concrete Research 79: 1-30, https://doi.org/10.1016/j.cemconres.2015.07.006.

\section{How can you contribute?}

To discuss this paper, please submit up to 500 words to the editor at journals@ice.org.uk. Your contribution will be forwarded to the author(s) for a reply and, if considered appropriate by the editorial board, it will be published as a discussion in a future issue of the journal. 